\title{
Advanced wound care: \\ from genetics to skin cell therapy
}

Ph.D. thesis

\section{Gábor Szabad}

\author{
Supervisor: \\ Lajos Kemény M.D., Ph.D., Dsc. \\ Department of Dermatology and Allergology \\ University of Szeged
}

Szeged, Hungary

2010 


\section{TABLE OF CONTENTS}

List of publications $\quad 4$

$\begin{array}{lr}\text { List of abbreviations } & 6\end{array}$

1. Introduction $\quad 7$

1.1. Leg ulcers

1.1.1. Background of chronic wounds

$\begin{array}{ll}\text { 1.1.2. Mechanism of wound healing } & 8\end{array}$

1.2. Overview of advanced wound care $\quad 9$

1.2.1. The basic goals of chronic wound care:

first - treat the cause, second - apply adequate local
wound care.

1.2.2. The non-healing wound: could leg ulcers be hereditary? 11

1.2.2.1. The role of fibroblast growth factor receptor 2 in
wound healing

1.2.2.2. The role of tumor necrosis factor $\alpha$ in wound healing $\quad 12$

$\begin{array}{lr}\text { 1.2.2.3. The role of syndecan } 4 \text { in wound healing } & 12\end{array}$

1.2.2.4. The role of neuropilin-1 in wound healing 12

1.2.3. Principles of wound care 13

$\begin{array}{ll}\text { 1.2.3.1. The non healing wound: common causes } & 13\end{array}$

1.2.3.2. Advanced local wound care 15

1.3. Aims 15

1.3.1. Genetic studies $\quad 15$

1.3.2. Local wound care 16

2. Materials and methods 16

2.1. Genetic studies 16

2.1.1. Human skin biopsy samples 16

2.1.2. Polymorphism analysis 17

2.1.2.1. SNP detection with the RT-PCR based
end point detection method

2.1.2.2. SNP detection with the PCR-RFLP method 17

$\begin{array}{ll}\text { 2.1.3. Gene expression studies } & 18\end{array}$

2.1.3.1. Analysis of gene expression on the

2.1.3.2. Analysis of gene expression on the protein
level (Western blot analysis)

2.1.4. Statistical analysis 19 
2.2. Local wound care studies

2.2.1. Autologous skin cell therapy 19

2.2.2. Human skin biopsy samples 21

2.2.3. Cell culturing 21

$\begin{array}{ll}\text { 2.2.3.1. Culture media } & 21\end{array}$

2.2.3.2. Cell culture techniques $\quad 22$

$\begin{array}{ll}\text { 2.2.3.3. Measurement of cell growth } & 23\end{array}$

$\begin{array}{ll}\text { 2.2.4. Transplantation } & 24\end{array}$

3. Results 25

3.1. Genetic studies 25

3.1.1. Predisposing Polymorphisms 25

3.1.1.1. SNP in the 3' untranslated region of the

3.1.1.2. SNP in the promoter region of the

$\begin{array}{ll}T N F-\alpha \text { gene }(-308 \mathrm{G} / \mathrm{A}) & 26\end{array}$

3.1.2. Gene expression abnormalities 26

3.2. Local wound care studies $\quad 27$

3.2.1. Artificial chemical mitogen free method to culture human adult melanocytes and keratinocytes $\quad 27$

3.2.2. Hairy scalp, the ideal donor site for split thickness and autologous keratinocyte-melanocyte transplantation 31

3.2.2.1. Autologous keratinocyte transplantation in wound healing

3.2.2.2. Split-skin grafting from the hairy scalp in wound healing

5. Discussion 36

$\begin{array}{ll}\text { 6. Future aspects } & 40\end{array}$

7. Acknowledgements 42

8. References 43 


\section{LIST OF PUBLICATIONS}

Publications directly related to the subject of the dissertation

I. Nagy N, Szolnoky Gy, Szabad G, Bata-Csörgő Zs, Dobozy A, Kemény L, Széll M: Single nucleotide polymorphisms of the fibroblast growth factor receptor 2 gene in patients with chronic venous insufficiency with leg ulcer. .

J Invest Dermatol 124: 1085-88, 2005.

IF: 4.406

II. Mohos G, Szabad G, Szolnoky Gy, Varga E, Kemény L: Lábszáron elhelyezkedő kiterjedt laphámrák kezelése izomlebeny és bőrtranszplantáció kombinációjával.

Magy Traumatol 49: 378-381, 2006.

IV.Szabad G: Modern sebkezelés, avagy a maggot-terápiától a bőrgyártásig.

Magyar Orvos 26-29, 2006.

V. Szabad G, Kormos B, Pivarcsi A, Széll M, Kis K, Kenderessy Szabó A, Dobozy A, Kemény L, Bata-Csörgő Z. Human adult epidermal melanocytes cultured without chemical mitogens express the EGF receptor and respond to EGF.

Arch Dermatol Res. 299: 191-200, 2007.

IF: 1.596

VI. Nagy N, Szolnoky Gy, Szabad G, Bata-Csörgő Zs, Balogh A, Klausz G, Mándi Y, Dobozy A, Kemény L, Széll M: Tumor Necrosis Factor-alpha -308 Polymorphism and Leg Ulceration - Possible Association with Obesity.

J Invest Dermatol. 127: 1768-9, 2007.

IF: 4.829

VII. Nagy N, Németh IB, Szabad G, Szolnoky Gy, Belső N, Dobozy A, Kemény L, Széll M: The altered expression of SDC4 in the uninvolved skin of venous leg ulcer patients may predispose to venous leg ulcer.

Wound Repair Regen. 16: 495-502, 2008.

IF: $\mathbf{2 . 4 4 5}$

VIII. Szabad G, Kosikné Vasas J, Sánta Cs, Kemény L: Modern sebkezelés, avagy a lárva terápiától a lökéshullámokig.

Sebkezelés, Sebgyógyulás. 12/1: 6-11, 2009.

IX.Szabad G: Korszerü sebkezelés.

Háziorvosi Továbbképző Szemle 15: 276-281, 2010. 


\section{Publications indirectly related to the subject of the dissertation}

1. Farkas Á., Szabad G., Michel, G., Ruzicka, T.: Interleukin-8 inhibitor izolálása polimorfonukleáris leukociták felülúszójából.

Bőrgyógy. Vener. Szle. 75: 107-111, 1999.

2. Kemény L, Kenderessy Szabó A, Kiss M, Szolnoky Gy, Gyulai R, Farkas Á, Szabad G, Michel G, Ruzicka T: Interleukin-8 inhibitor izolálása polimorfonukleáris leukociták felülúszójában.

Bőrgyógy Vener Szle 75: 107-111, 1999.

3. Haak-Frendscho, M., Darvas Zs., Hegyesi H., Kárpáti S., Hoffmann, R.L., László V., Bencsát M., Szalai Cs., Fürész J., Timár J., Bata-Csörgő Zs., Szabad G., Pivarcsi A, Pállinger É., Kemény L., Horváth A., Dobozy A., Falus A.: Histidine decarboxylase expression in human melanoma.

J Invest. Dermatol 115: 345-352, 2000.

IF: 4.539

4. Oláh J, Gyulai R, Baltás E, Szabad G, Németh R: A digitális dermatoszkópia és computeres képanalízis jelentősége a bőrgyógyászati gyakorlatban.

Bőrgyógy Vener Szle 80: 269-274, 2004. 


\section{LIST OF ABBREVIATIONS}

AHS

Autologous human serum

BPE

Bovine pituitary extract

CSF-1

Colony stimulating factor

DNA

Deoxyribonucleic acid

EGF

Epidermal growth factor

ET-1

Endothelin-1

FBS

Fetal bovine serum

bFGF

Basic fibroblast growth factor

FGF

Fibroblast growth factor

FGFR2

Fibroblast growth factor receptor 2

IL-1

Interleukin-1

KBM

Keratinocyte basal media

KGF

Keratinocyte growth factor

KGFR

Keratinocyte growth factor receptor

MGM

Melanocyte growth media

$\alpha \mathrm{MSH}$

$\alpha$ Melanocyte stimulating hormone

NRP1

Neuropilin-1

PCR

Polymerase chain reaction

PDGF

Platelet derived growth factor

RNA

Ribonucleic acid

SDC4

Syndecan-4

SNP

Single nucleotide polymorphism

TGF- $\beta$

Transforming growth factor $\beta$

TNF- $\alpha$

Tumor necrosis factor $\alpha$

TNFR 1-2

Tumor necrosis factor receptor 1-2

TPA

12-O-tetradecanoyl phorbol-13-acetate

V.A.C.

Vacuum assisted closure

VEGF

Vascular endothelial growth factor

VEGFR

Vascular endothelial growth factor receptor 


\section{INTRODUCTION}

\subsection{Leg ulcers}

\subsubsection{Background of chronic wounds}

The number of chronic wound patients is increasing world wide, despite the fact that the last twenty years have seen major innovations in wound healing. Unfortunately this also means a steep rise in the number of lower limb amputations due to previous tissue loss. Chronic wounds are a growing challenge due to demographic changes and increased risks of atherosclerosis and diabetes. In developing countries the prevalence of diabetes is about 5$7 \%$, and it is estimated that $15 \%$ of all diabetic foot ulcers will result in amputations (Figure 1). Both tissue loss and amputations have an enormous impact on one's everyday life resulting in social isolation, loss of independence, psychological stress and increased health costs for the patient and the society as well. These health costs already present a significant economic problem for health care providers, and with the patient numbers increasing they forecast a boom in expenses in the near future.
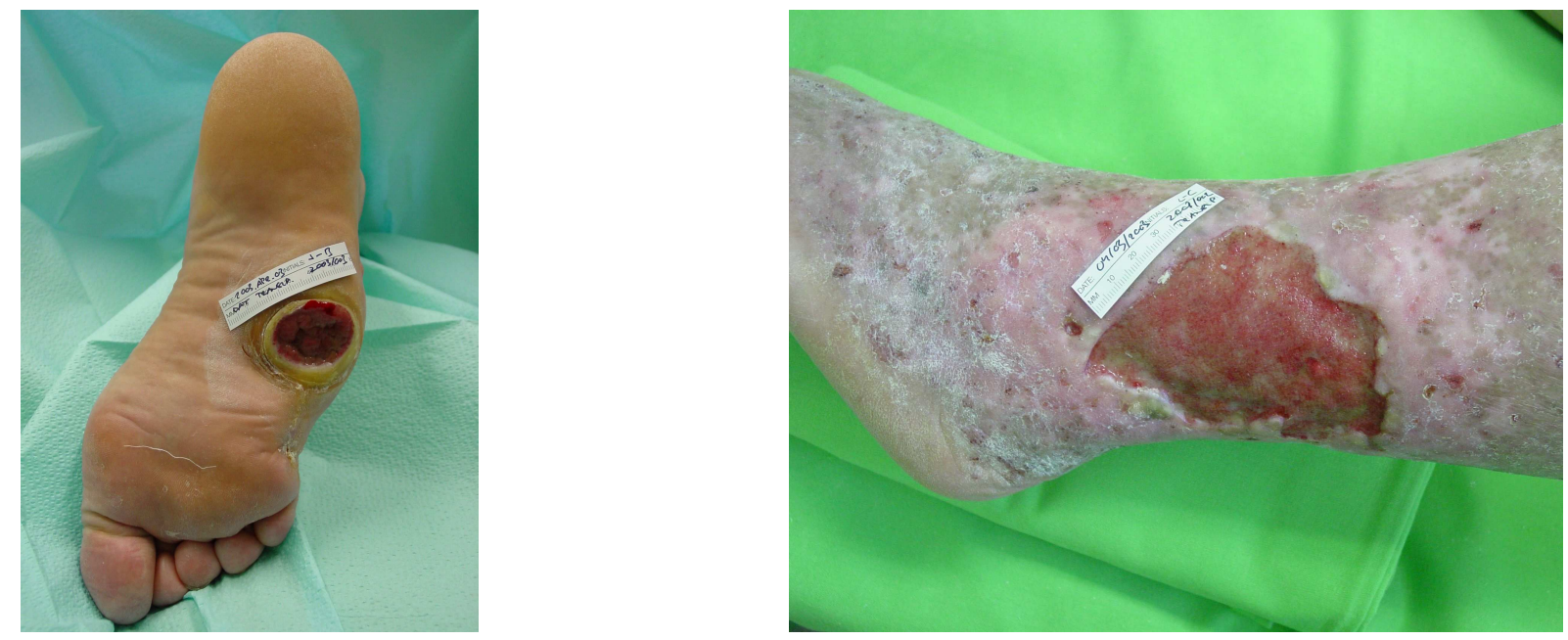

Figure 1. - Chronic leg ulcers of the lower limb

The abundance of wound care methods and products resulted in an information boom regarding wound healing, making every day decision making harder. Treating a wound properly now equals to establishing a complex care strategy for the patient with the involvement of a multidisciplinary wound care team. 


\subsubsection{Mechanism of wound healing}

The normal wound healing process takes around 7 - 14 days to complete. It has three main phases: inflammation, proliferation and remodeling with wound contraction. During the inflammation phase, various vasoactive mediators are excreted by thrombocytes due to coagulation, activated complement pathways and injured parenchymal cells. These substances recruit inflammatory leukocytes, which clean the wounded area. At the same time, the infiltrating monocytes become activated macrophages and release growth factors such as platelet-derived growth factor (PDGF) and vascular endothelial growth factor (VEGF), which initiate the formation of granulation tissue. Macrophages also express colony-stimulating factor 1 (CSF-1), a cytokine necessary for the survival of monocytes and macrophages, tumor necrosis factor $\alpha$ (TNF- $\alpha$ ), a potent inflammatory cytokine, transforming growth factor $\beta$ (TGF- $\beta$ ) and interleukin-1 (IL-1). Macrophage-depleted animals exhibit defective wound repair and therefore macrophages seem to be essential in the transition between inflammation and repair (Clark et al., 1996; Toumi et al., 2006).

The phase of tissue formation is characterized by re-epithelialization and neoangiogenesis. During re-epithelization, epidermal cells located at skin appendages and at wound edges undergo marked phenotypic alterations including the retraction of tonofilaments, the dissolution of desmosomes, and cytoplasmic actin filament formation. Migrating epidermal cells separate the non-viable and viable parts of wounds. This process is determined by integrin receptors expressed on the surface of migrating cells. The extracellular matrix viability primarily depends on the production of collagenase and plasminogen activator. The processes of migration and proliferation are attributed to the absence of neighbor cells, locally released growth factors and especially fibroblast growth factors (FGFs) and their receptors (Werner et al., 1994; Paladini et al., 1996; Singer and Clark, 1999).

The formation of new blood vessels is necessary to sustain the newly formed granulation tissue. The induction of angiogenesis was initially attributed to FGFs, but several other molecules have also been found to exert angiogenic activity, such as VEGF, TGF- $\beta$, angiogenin, angiotropin, angiopoietin 1 and thrombospondin (DiPietro et al., 1996; Nissen et al., 1998). A low oxygen tension and elevated levels of lactic acid may also stimulate angiogenesis (Laurens et al., 2006).

Fibroblasts residing in the dermis are responsible for the synthesis, deposition and remodeling of the extracellular matrix. The provisional extracellular matrix is gradually replaced by a collagenous matrix. Once collagen matrix has been deposited in a wound, the 
granulation tissue is replaced by a relatively acellular scar. Dysregulation of these processes results in fibrotic disorders such as keloid formation, morphea and scleroderma (Singer and Clark, 1999; Holmbeck et al., 2006).

The last phase of wound healing is tissue remodeling: during the second week of healing, the fibroblasts assume a myofibroblast phenotype characterized by large bundles of actin filaments. The appearance of myofibroblasts corresponds to the commencement of connective tissue compaction and the contraction of the wound. TGF- $\beta$ and PDGF are essential factors for contraction. Collagen remodeling during the transition from granulation tissue to scar is controlled by proteolytic enzymes, matrix metalloproteinases, which are secreted by macrophages, epidermal cells, endothelial cells and fibroblasts (Holmbeck et al., 2006).

\subsection{Overview of advanced wound care}

\subsubsection{The basic goals of chronic wound care: first - treat the cause, second - apply adequate local wound care.}

In the case of acute wounds normal wound healing is described as a cascade of physiological events resulting in full epithelisation. In chronic wounds these events often take place not one by one, but at the same time. A chronic wound is defined as a break in the skin of long duration (more than 6 weeks). Analyzing a chronic wound, one must attempt to determine which aspect of the healing process gone wrong and why. It should be carefully assessed whether it is the result of local or systemic microenvironmental factors. With this approach, chronic wound can be considered as a symptom of an underlying disease.

For most cases successful wound healing is based on two pillars (goals): treating the underlying cause or disease behind the chronic wound and adequate local wound care resulting in a wound bed ready for epithelisation. Evidently, accomplishment of only one of these two goals will never result in long term success.

\subsubsection{The non-healing wound: could leg ulcers be hereditary?}

The ulceration of the leg is a multifactorial disorder with several known and yet unknown environmental and genetic factors contribute to its etiology. To study the genetic factors involved in the mechanism of leg ulcer development and to minimize statistical bias, we have chosen one of the major homogenous subgroup of leg ulcers, therefore our genetic 
studies were carried out on patients with venous leg ulcer. The complexity of venous leg ulcer pathogenesis is increased by the fact that in the majority of the cases its development has polyetiological origin. Besides environmental factors, several predisposing genetic factors have already been shown to be associated with venous leg ulcer susceptibility such as the presence of certain gene polymorphisms and gene expression abnormalities (Table 1.). The known genetic factors predisposing to venous leg ulcer development are the followings factor V Leiden mutation, prothrombin gene G20210A mutation, antithrombin deficiency, activated protein $\mathrm{C}$ resistance, protein $\mathrm{S}$ deficiency, hyperhomocysteinaemia and abnormal TGF- $\beta$ type 2 receptor expression (Munkvad et al., 1996; Peus et al., 1997). These genetic factors impair different processes and phases of wound healing, which might suggest that multiple molecular mechanisms of venous leg ulcer development exist or similarly to carcinogenesis the coexistence of different precipitating factors leads to the development of the disease. To develop causative treatment opportunities for those who have genetic deficiencies in the pathogenesis, there is an emerging importance to characterize the genetic abnormalities of leg ulcer development.

\begin{tabular}{|c|c|c|c|c|}
\hline \multicolumn{5}{|c|}{ Putative genetic factors in the development of venous leg ulcer* } \\
\hline Author & Journal & Year & Detected genetic abnormality & Population \\
\hline 1.Peus et al. & J Am Acad Dermatol & 1996 & Factor V, R506Q variant (FV Leiden) & German \\
\hline 2. Jebeleanu et al. & J Cell Mol Med & 2001 & Prothrombin gene, G20210A mutation & Romanian \\
\hline 3. Gemmati et al. & Wound Repair Regen & 2004 & Factor XIII, V34L polymorphism & Italy \\
\hline 4. Nagy et al. & J Invest Dermatol & 2005 & FGFR2, A2451G 3' UTR polymorphism & Hungarian \\
\hline 5. Ashworth et al. & J Steroid Biochem Mol Biol & 2005 & Estrogen receptor $\beta$, CA repeat & UK \\
\hline 6.Zamboni et al. & J Vasc Surg & 2005 & Hemochromatosis gene, $\mathrm{C} 282 \mathrm{Y}$ mutation & Italy \\
\hline 7. Wallace et al. & $\mathrm{J}$ Invest Dermatol & 2006 & $\mathrm{TNFa},-308$ promoter polymorphism & Australian \\
\hline 8. Gemmati et al. & J Vasc Surg & 2009 & FPN1 gene, -8GG & Italy \\
\hline 9. & & & MMP12 gene, $-82 \mathrm{AA}$ & \\
\hline \multicolumn{5}{|c|}{$\begin{array}{l}\text { *Clinical relevance: before these data are considered as susceptibility factors for leg ulcer, further larger studies } \\
\text { in different populations are needed. }\end{array}$} \\
\hline \multicolumn{5}{|c|}{ Putative genetic factors in the development of diabetic foot ulcer* } \\
\hline Author & Journal & Year & Detected genetic abnormality & Population \\
\hline 1. Cheng et al. & J Diabetes Complications & 2009 & OPRM1, A118G polymorphism & Taiwanese \\
\hline 2. Mir et al. & Br J Surg & 2009 & HSPA1B gene, G1538A mutation & Indian \\
\hline 3. & & & HSPA1L gene, C2437T mutation & \\
\hline
\end{tabular}

Table 1. - Putative genetic factors predisposing to venous leg ulcer (a) and diabetic foot ulcer (b) development. 


\subsubsection{The role of fibroblast growth factor receptor 2 in wound healing}

The isoforms of the proteins coded by the fibroblast growth factor receptor 2 gene (FGFR2), plays complex roles in the process of wound healing and are active in all phases. In the process of re-epithelization, the control of keratinocyte proliferation is attributed to FGFR2-IIIb signaling through mediation of the effects of FGF-7 keratinocyte growth factor 1 (KGF-1) and FGF-10 (KGF-2; Maas-Szabowski et al., 2001), while the induction of woundrepair-associated neoangiogenesis is attributed to FGFR2-IIIc signaling.

Upon injury-induced IL-1 stimulation, FGF are expressed primarily in fibroblasts during the tissue formation phase of wound healing. After being excreted, the FGFs diffuse into the upper layer of the skin and bind specifically to their receptor, FGFR2-IIIb keratinocyte growth factor receptor (KGFR). Due to the receptor-ligand interactions between FGFs and FGFR2-IIIb, signal transduction mechanisms are initiated, and hence the keratinocytes commence to proliferate (Maas-Szabowski et al., 2001).

During neoangiogenesis, macrophages are located in the granulation tissue and release FGFs. The FGFs bind to their receptor, FGFR2-IIIc, and stimulate the endothelial cells. Due to this receptor-ligand interaction, endothelial cells excrete plasminogen activator and procollagenase. Plasminogen activator converts plasminogen to plasmin and procollagenase to active collagenase, and these proteases digest the basement membrane of blood vessels. The fragmentation of basement membrane allows endothelial cells to migrate and form new blood vessels at the injured site (Singer and Clark, 1999).

\subsubsection{The role of tumor necrosis factor $\alpha$ in wound healing}

Tumor necrosis factor $\alpha(\mathrm{TNF}-\alpha)$ is a potent pleiotropic, pro-inflammatory cytokine that belongs to the TNF superfamily. In the course of an injury or an infection, the soluble TNF- $\alpha$ is released from macrophages and endothelial cells due to IL- 1 and/or bacterial endotoxin stimulation and binds to its receptors: the TNF receptor 1 (TNFR1) and 2 (TNFR2), both of which have cell surface and soluble forms as well (Hotamisligil et al., 1997).

TNF- $\alpha$ mediates a number of biological processes, including lipid metabolism, coagulation, insulin resistance, endothelial functions and wound healing (Crist et al., 2004). Moreover, it plays a key role in the inflammation phase of normal wound healing. As growing numbers of evidences suggest, TNF- $\alpha$ has an essential function in the healing of pathological wounds such as venous leg ulcers. Wallace and Stacey (1998) demonstrated that the level of TNF- $\alpha$ is down-regulated in the wound fluid from non-healing venous leg ulcers as compared 
with healing venous leg ulcers. Further, it has recently been proved that the topical application of TNF- $\alpha$ antibody (infliximab) improves the healing of chronic wounds (Streit et al., 2006).

\subsubsection{The role of syndecan-4 in wound healing}

Syndecan-4 (SDC4) is a heparan sulfate proteoglycan expressed on the surface of most adherent mammalian cells. It is essential for cell-matrix junction formation such as focal adhesions. SDC4 interacts with integrins in response to fibronectin and modulates cell behavior such as adhesion, migration, and proliferation. A considerable amount of evidence suggests the complex role of SDC4 in wound healing. Immunodepletion of SDC4 in wound fluid reduces proteolytic activity and indicates that proteases in the wound environment are regulated by interactions with SDC4. During granulation tissue formation, the expression of SDC4 is transiently increased in human and murine neonatal skin, which correlates with the up-regulation of proliferation. SDC4 knock-out mice show delayed wound healing due to failure to form granulation tissue and impaired angiogenesis. With a yet unknown mechanism, SDC4 modulates cytoplasmic and extracellular interactions of growth factor tyrosine kinase receptors. In addition, platelet-derived growth factor, a well-known chemotactic factor in the inflammatory phase of wound healing, strongly up-regulates the expression of SDC4 in fibroblasts. So far, there is only one study in the literature that compares SDC4 expression profiles in skin biopsy samples collected from the wound edge and from uninvolved skin of 11 chronic venous leg ulcer patients. It was demonstrated that the expression of SDC4 was mostly pericellular in samples that derived from the wound edge, while it was mainly intracellular in the uninvolved skin samples. Whether there are abnormalities in the expression profile of SDC4 in intact skin of venous leg ulcer patients compared with healthy individuals has not been demonstrated by the authors.

\subsubsection{The role of neuropilin-1 in wound healing}

Neuropilin-1 (NRP1) is a transmembrane receptor for semaphorin and VEGF isoforms. It is expressed in neurons, endothelial cells, and also in keratinocytes and plays versatile roles in angiogenesis, axon guidance, cell survival, migration, and invasion. In vivo and in vitro dermal wound repair models demonstrated that NRP1 is a co-receptor of vascular endothelial growth factor receptors (VEGFR) and is involved in the VEGF-mediated angiogenesis associated with dermal wound repair. However, NRP1 binds semaphorin in the epidermis in a plexin-dependent manner and plays a role in the regulation of keratinocyte migration. Earlier studies analyzed the role of NRP1 in the process of normal wound healing, 
but not in diseases with wound-healing abnormalities such as venous leg ulcer. Increasing data in the literature suggest a connection between NRP1 and SDC4. It has been reported that NRP1 binds FGF2 and modulates its signaling via its receptor, FGFR2, while SDC4 is a wellknown co-receptor of FGFR2 with the binding ability both to FGF2 and FGFR2, and its overexpression leads to enhanced FGF2 signaling. Furthermore, NRP1 mediates the effects of VEGF and enhances the angiogenic signal cooperatively with VEGFR2, while SDC4 is upregulated in parallel with VEGF in fibroblasts and endothelial cells cultured under hypoxic conditions.

\subsubsection{Principles of wound care}

\subsubsection{The non healing wound: common causes}

Common causes of chronic wounds are basically of two types: vascular and non vascular. Vascular causes could affect the venous, arterial and lymphatic system. Non vascular causes are mainly linked to diabetic neuropathy, pressure ulcers, infection, immunological defects and malignancies.

Venous ulcers account for the majority of all lower limb wounds. It is estimated, that around 2-3\% of the adult population is affected (Phillips et al., 1991). The origin is usually venous thrombosis and/or reflux through incompetent valves resulting in venous hypertension and insufficiency. Histories of the patients include swelling, varicose veins and serious pains of the legs by the end of the day. On physical examinations, ulcers are typical in the gaiter area, with oedema, pigmentation and prominent veins. In more serious cases the ulcer involves the lower limb circumferentially, with marked indurations, hemosiderosis, lipodermato-sclerosis, atrophie blanche and often stasis dermatitis. Management should focus on the restoration of venous insufficiency to the highest achievable degree, namely compression therapy, possibly endovenous and venous surgery and hosiery. In most cases long term success is dependant on proper compression therapy.

In general arterial ulcers are a consequence of inadequate blood supply to the skin, resulting in tissue necrosis. Arterial disease is present in about $25 \%$ of patients with leg ulcers (Baker et al., 1992). Mixed arterial and venous ulcers are also not uncommon. The most common cause is atherosclerosis (often called ischemic arterial ulcer), although diabetic arterial and renal arterial ulcers are also common. History of the patients contains claudication, rest pain, ulceration and gangrene. On physical examination in ischemic arterial 
ulcers we find absent or hardly detectable pulses, cold feet, pale skin and painful ulcers on the finger tips. Management should focus on endovascular or surgical arterial restoration.

Lymphatic ulcers form on the basis of lymphoedema, which can be primary (hereditary) and secondary. Secondary lymphoedema is always the cause of either excess lymph production or an obstruction in lymph drainage. History of the patient usually includes previous inflammation, trauma of the limb, possibly a malignancy. On physical examination we find swelling, in earlier stages pitting, in advanced forms non-pitting oedema and in severe cases an elephantine look of the affected limb. Liposuction in non pitting lymph- and lipoedema and, in very rare cases, microsurgical procedures for the anastomoses of the lymphatic and venous vessels could also be a treatment of choice.

Diabetic patients have 25\% lifetime risk of developing a foot ulcer (Young et al., 1993; Boulton et al., 1988). It is estimated that up to $15 \%$ of all foot ulcers will result in amputations (Frykberg et al., 2000). Diabetic foot ulcers are usually the consequences of diabetes associated peripheral neuropathy and vascular disease affecting both the macro- and microvasculature. Peripheral motor neuropathy will result in atrophy of the intrinsic muscles of the foot resulting in structural deformities. Should this be coupled with sensory neuropathy it is only the matter of time for wound formation due to unfelt mechanical stress. In most patients a callus will form, clearly marking pressure points on the foot. Wound healing is usually worsened by impaired immunological functions, poor blood sugar control, poor tissue oxygenisation due to loss of autonomous regulation and vasomotion of the microvasculature. Increased risk of wound infection unfortunately often results in osteomyelitis. Management is outlined with regular debridements and keratotomy, use of protective footwear et al.1 times and in the case of plantar ulcers the use of custom-made off-loading devices. The importance of regular follow-up cannot be overstated.

Pressure ulcers form when tissue compression exceeds the capillary filling pressure and results in local ischemia and the subsequent necrosis after two hours. This is usually the result of prolonged pressure, friction or shear. The most vulnerable sites are areas of the body where skin is overlying boney prominences, like the sacrum, hips, etc. Immobile patients are at the highest risk.

Rare type of ulcers, atypical location, morphology and history pose interesting situations. As a central rule, if an ulcer appears at an atypical location, with atypical history and morphology, skin biopsy from the periwound area has to be taken. Rare cases of non healing wounds should always be diagnosed with histological evaluation. In most cases the underlying disease is malignancy or an immunological disorder. 


\subsubsection{Advanced local wound care}

The basic goal of local wound care is to prepare a wound bed ready for epithelisation in the shortest, safest, pain free manner in the most cost-effective possible way. This simple goal has been around since ancient Greek physician Galen of Pergamun who noted that wounds heal optimally in a moist wound environment. For some reason this ancient principle was forgotten and drying the wound bed was the main goal of local wound care until the 1960s. The latter half of the $20^{\text {th }}$ century saw enormous research and development in the field of moist wound care. This subsequently led to the birth of modern, moist wound care dressings. The main goal of these wound dressings is to maintain and protect a moist wound environment with the possible capability to absorb the excess exudates to prevent maceration. There are numerous dressing categories used today and the main types for the wound surface are: gauzes, films, hydrogels, hydrocolloids, alginates, foams, collagens and silver or iodine containing antimicrobial dressings. Besides the use of modern moist wound dressings a wide array of wound care methods have been developed to solve common wound bed disorders.

\subsection{Aims}

\subsubsection{Genetic studies}

Most of the chronic leg ulcers can be classified into one of the following categories described before. However, some of the wounds fail to heal even after causative treatments. These leg ulcers are considered as highly recalcitrant forms and increasing number of evidence suggest that they are the consequences of combined (acquired and inherited) etiological factors or multi-etiological factors (Fowkes et al., 2001; Abbade et al., 2005). In these cases, besides the characteristic acquired etiological factor such as venous insufficiency, there is a putative inherited etiological factor thet al.so contributes to the mechanism of delayed or pathologic wound healing and thus to the development of leg ulcer. Therefore the delineation of the molecular mechanisms of pathologic wound healing might lead to the development of causative treatment opportunities for these therapy-resistant forms as well.

The aims of our genetic studies were to identify common single nucleotide polymorphisms (SNP), which are associated with leg ulcer development and gene expression abnormalities related to pathologic wound healing. 


\subsubsection{Local wound care}

In chronic leg ulcers and extensive two and three degree burns autologous keratinocyte transplantation is a new line of treatment instead of conventional split thickness grafts. In such cases autologous keratinocytes are prepared and cultured from the patient's own skin. Donor site for such skin samples is usually the groin, the upper leg and arm. Since hair follicles contain a high number of undifferentiated keratinocytes, we hypothesized that keratinocyte cultures established from hairy scalp would have a better mitotic potential making them more suitable for keratinocyte transplantation.

We aimed to develop a new autologous skin cell transplantation method that uses the hairy scalp as a donor site, with an artificial mitogen free culturing method containing melanocytes, fibroblasts and keratinocytes.

\section{MATERIALS AND METHODS}

\subsection{Genetic studies}

\subsubsection{Human skin biopsy samples}

Size 2 × $2 \mathrm{~cm}$ shave biopsies were collected under local anesthesia from venous leg ulcer patients $(n=15)$ and from age and sex-matched leg ulcer-free control individuals $(n=15)$. Leg ulcer patients were enrolled into the study if the duration of the presence of the leg ulcer exceeded 6 weeks. The average duration of the ulcers was $5.8 \pm 5.1$ years and $24.2 \%$ of the leg ulcer patients had deep vein thrombosis previously. Leg ulcer patients with diabetes of either type 1 or type 2 or with arterial disease were excluded from the study. Venous leg ulcer patients were also screened for trauma, erysipelas, cardiac diseases, atherosclerosis and autoimmune disorders. The study was approved by the Internal Review Board. Written informed consent was received from all donors and the study was conducted according to the Principles of the Declaration of Helsinki. 


\subsubsection{Polymorphism analysis}

\subsubsection{SNP detection with RT-PCR based end point detection method}

Blood samples were collected from patients with leg ulcer $(n=82$, average age: $67 \pm 24.8$ years) and from the members of an age-matched control group ( $n=82$, average age: $53 \pm 29.2$ years). DNA was isolated by standard proteinase $\mathrm{K}$ digestion (DNA Isolation Kit, Eppendorf). PCR reactions were carried out on all the samples with TaqMan mutation detection probes (Assays-on-Demand SNP Genotyping Kit, Applied Biosystems).

The Assays-On-Demand SNP Analyzing Mix contains two main components: specific primers for the amplification of a short DNA fragment involving the examined SNP and oligonucleotides labeled with detector fluorescent dyes. The sequences of the labeled oligonucleotides differ from each other only in one nucleotide in the position of the polymorphism and the oligonucleotide is labeled with one of the dyes (FAM or VIC). During the PCR reaction, one or both of the oligonucleotides bind to the DNA amplicon, depending on the genotype of the examined individual, and is cut into fragments by the exonuclease activity of the Taq DNA polymerase. Thus, at the end of the PCR reaction, the fluorescent signal of one or both of the cut fragments can be detected.

PCR reactions were performed in a total volume of $25 \mu \mathrm{l}$ containing $100 \mathrm{ng}$ of template genomic DNA, 1.25 $\mu \mathrm{l}$ of Assays-on-Demand SNP Analysis Mix and $12.5 \mu \mathrm{l}$ of Reaction Mix (Applied Biosystems). All of the examined genomic DNA templates were measured in duplicates.

After completion of the PCR reactions end-point detection was performed with an ABI Prism 7000HT Sequence Detection System. The statistical significance of the differences between data distributions was determined by using the $\mathrm{Chi}^{2}$ probe and a probability level $\mathrm{P}<0.05$ was considered statistically significant.

\subsubsection{SNP detection with the PCR-RFLP method}

Blood samples were collected from all participants $(n=282)$, DNA was isolated by a standard proteinase K digestion method (Eppendorf AG, Hamburg, Germany). The TNF- $\alpha$ 308 G/A SNP was genotyped by a PCR with restriction fragment length polymorphism 
method: $100 \mathrm{ng}$ of genomic DNA was used for PCR amplification and a 147-nucleotide region of the TNF- $\alpha$ promoter harboring the SNP was amplified by PCR, using the following primers: forward 5' - GAGGCAATAGGTTTTGAGGGCCAT - 3', reverse 5' GGGACACACAAGCATCAAG - 3'. Restriction enzyme digestion - with NcoI (Fermantas, Vilnius, Lithuania) - was performed to distinguish the $-308 \mathrm{G} / \mathrm{A}$ alleles, using $10 \mu \mathrm{l}$ of the PCR products, run on 5\% Nusieve agarose gels (Cambrex, Berkshire, UK) and photographed. The amplified wild-type (GG) PCR product was cut at one position by NcoI, resulting in 121and 26-nt bands, the amplified homozygote mutant (AA) PCR product was not cut; therefore, the original 147-nt PCR product was detected, and the heterozygote mutant genotype was characterized by a pattern of 147-, 121- and 26-nucleotidet products.

\subsubsection{Gene expression studies}

\subsubsection{Analysis of gene expression at mRNA level (real-time RT-PCR)}

Total RNA was isolated from samples through the use of the TRIzol reagent, following the instructions of the manual. cDNA was generated with oligo(dT) and random hexamer primers from $1 \mu \mathrm{g}$ RNA using the iScriptTM cDNA Synthesis Kit of Bio-Rad Laboratories (Hercules, CA, USA) in a final volume of $20 \mu \mathrm{l}$. Then real-time RT-PCR was performed to quantify the abundance of the mRNA (actually the cDNA) concentration in each of the examined samples. TaqMan probes were purchased from IDT Probes (Chicago, IL, USA). The real-time RT-PCR reactions were conducted by using iQ Supermix (Bio-Rad Laboratories) in an iCycler (Bio-Rad Laboratories).

\subsubsection{Analysis of gene expression on the protein level (Western blot analysis)}

Total protein extracts were prepared from the skin biopsy samples using TRIzol reagent according to the instructions of the manual. In order to verify the equivalent loading of proteins in the wells, the following procedure was carried out: based on the measured density $\mathrm{OD}_{280}$, the protein concentration of each sample was calculated, and the samples were then run on $10 \%$ SDS-polyacrylamide gel electrophoresis (SDS-PAGE). The gels were stained with Coomassie brilliant blue (CBB; Sigma-Aldrich), dried and scanned. The lanes were analyzed by densitometry. The amounts of the loaded protein samples were corrected according to the densitometry data and checked again on SDS-PAGE.

For Western blot analysis, equal amounts of proteins were run on SDS-PAGE gel and then transferred to nitrocellulose membrane (Bio-Rad Laboratories). The membranes were 
blocked by incubation in Tris-buffered saline (150 mM NaCl, $25 \mathrm{mM}$ Tris, $\mathrm{pH}$ 7.4) containing 0.05\% Tween 20 (Sigma-Aldrich) and 3\% non-fat dry milk (Fluka Chemie AG, Neu-Buchs, Switzerland) for $2 \mathrm{~h}$ at room temperature and subsequently incubated overnight on $4^{\circ} \mathrm{C}$ with the primary antibodies (Santa Cruz Biotechnology, Inc., Santa Cruz, CA, USA) in a dilution of $1: 100$.

Besides FGFR2-IIIb, the protein expression of a differentiation marker, K10 was also detected with a mouse monoclonal antibody (Dako A/S, Glostrup, Denmark) in a dilution of 1:500. Alkaline phosphatase-conjugated goat anti-rabbit IgG and anti-mouse IgG (SigmaAldrich) were used as secondary antibodies at a dilution of 1:4000 dilution in the blocking buffer for $2 \mathrm{~h}$ at room temperature. The blots were developed by using 5-bromo-4-chloro-3indolyl phosphate/nitroblue tetrazolium as substrate (Sigma-Aldrich).

\subsubsection{Statistical analysis}

Statistical analysis, on the groups of leg ulcer patients and leg ulcer-free controls, was carried out according to the rules of case-control allelic association study design. The statistical significance of the association between the mRNA or protein expression profiles of the different genes and venous leg ulcer development was assessed by one-way ANOVA for two independent samples. The statistical significance of the association between the examined SNPs of FGFR2 and venous leg ulcer was determined with the $\mathrm{Chi}^{2}$ probe. The Bonferroni correction for the multiple hypothesis of the analyzed different SNPs $(n=5)$ was also defined. The statistical significance of the association between the -308 TNF- $\alpha$ SNP and venous leg ulcer was calculated by means of the Fisher Exact Probability Test. To allow comparison with the findings of Wallace et al. (2006), logistic regression analysis was also carried out. For all SNPs, odds ratios (ORs) with 95\% confidence intervals (CIs) were also determined. All statistical analyses were carried out through the use of VassarStats (http://faculty.vassar.edu/lowry/VassarStats.html).

\subsection{Local wound care studies}

\subsubsection{Autologous skin cell therapy}

Treatment of chronic leg ulcers and extensive two and three degree burns unite in the same goal: to provide the absent autologous skin cells. This is accomplished by tissue engineering, a new and interdisciplinary field that aims to solve the critical medical problems of tissue loss and organ failure. In today's practice a small skin specimen is taken from the 
patient as a full thickness sample from the groin, or as a split thickness graft from the upper leg or arm. Epidermal cell suspension is prepared and plated in vitro. Within two to three weeks and following several passages a pure keratinocyte culture is established which then is transplanted into the wound bed. Keratinocytes attach to the wound bed and produce a wide array of growth factors and fasten the healing process. Since the grafted keratinocytes are autologous there is no immunological reaction involved in this transplantation technique.

Hair follicles contain a higher number of undifferentiated keratinocytes, thus keratinocyte cultures established from the hairy scalp should have a better mitotic potential, making them more suitable for keratinocyte transplantation. 


\subsubsection{Human skin biopsy samples}

We took biopsies from six patients after approval of the study protocol by the Ethical Committee of the University of Szeged. All patients were informed of the procedures and all have signed the consent form. The samples were taken from three different sites under local anesthesia: split skin graft of the hairy scalp, full thickness graft of the groin and split thickness graft of the upper leg (Figure 2). All samples were $9 \mathrm{~cm}^{2}$ in size. Each individual (ages 61-74) had chronic leg ulcers for over ten years.

a
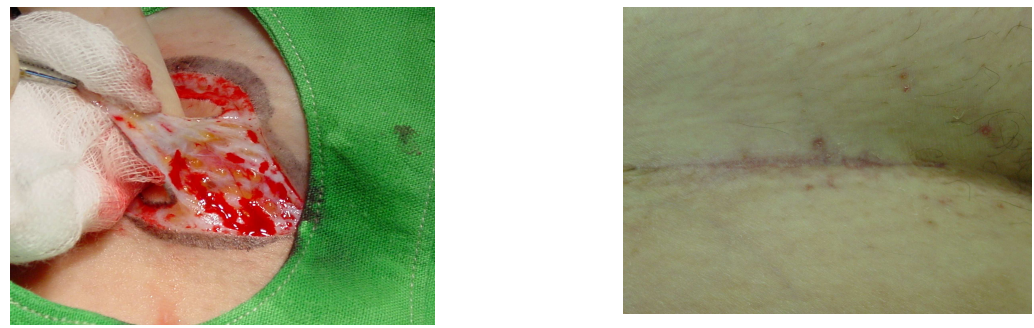

b
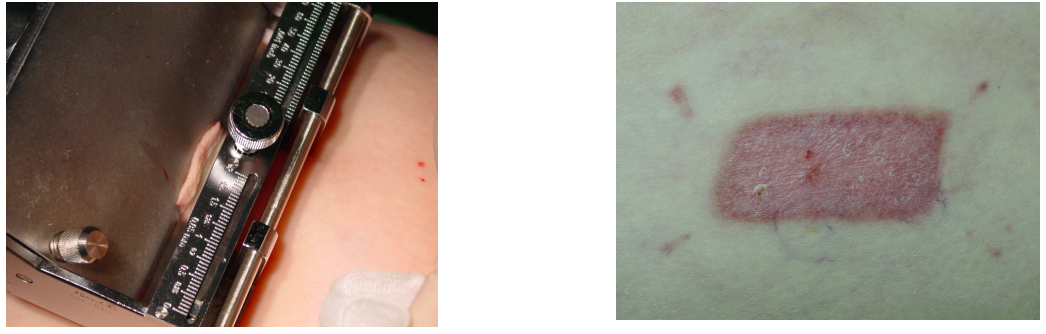

$\mathrm{c}$
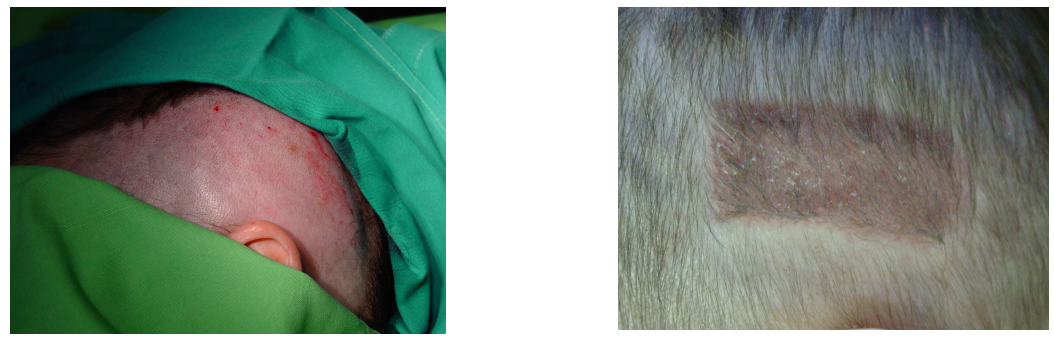

Figure 2. - Different donor sites on the left, with healed status on the right.

Note hair growth after split skin harvesting at the hairy scalp.

( $\mathrm{a}$ - groin; $\mathrm{b}$ - thigh; $\mathrm{c}$ - hairy scalp)

\subsubsection{Cell culturing}

\subsubsection{Culture media}

The new culture medium consisted of AIM-V serum free lymphocyte medium and Keratinocyte Basal Medium (both from Gibco BRL, Eggstein, Germany), v:v (as basal 
medium, Mel-mix), supplemented with 2.5\% Fetal Bovine Serum (FBS) (Gibco), Epidermal Growth Factor (EGF) $2.5 \mathrm{ng} / \mathrm{ml}$ (Gibco), Bovine Pituitary Extract (BPE) $25 \mu \mathrm{g} / \mathrm{ml}$ (Gibco), LGlutamine and antibiotic/antimycotic solution containing $100 \mathrm{U} / \mathrm{ml}$ penicillin, $100 \mu \mathrm{l} / \mathrm{ml}$ streptomycin and $100 \mu \mathrm{l} / \mathrm{ml}$ amphotericin B (Sigma Laboratories, Budapest, Hungary). With the above supplements we call the medium complete Mel-mix.

In a series of experiments we compared the effect of FBS, EGF and BPE separately and together on the in vitro growth of melanocytes. To prepare a medium free of animal derivatives we substituted FBS with the patient's autologous serum and left out BPE. Culturing with chemical mitogens was performed with the addition of 12-O-tetradecanoyl phorbol-13-acetate (TPA) $10 \mathrm{ng} / \mathrm{ml}$ (Sigma) to the complete Mel-mix medium.

\subsubsection{Cell culture techniques}

Adult epidermal melanocytes were isolated and cultured from breast or trunk skin specimens of healthy Caucasian donors undergoing plastic surgery. Skin specimens were first washed in Salsol A solution (Human Rt, Gödöllö, Hungary) supplemented with 2\% antibiotic, antimycotic solution (Sigma). The subcutis and part of the dermis was removed and the tissue was cut into small strips. Overnight incubation in Dispase solution (Grade II, Roche Diagnostics, Mannheim, Germany) was carried out at $4^{\circ} \mathrm{C}$ to separate the dermis from the epidermis (Kitano et al., 1983). The epidermis was peeled of the dermis next day. To prove that the use of dispase prevents fibroblast contamination, we isolated RNA both from the epidermis and the dermis after dispase treatment and performed real-time RT-PCR using primers specific for COL1A2, the gene that encodes for the alpha 2 chain of type I collagen. We could not detect COL1A2 gene expression in the epidermal sample. Thus, the use of dispase prevents fibroblast contamination in the epidermal cell cultures. The epidermis was put into $0.25 \%$ trypsin (Gibco) for 30 minutes at $37^{\circ} \mathrm{C}$. Following trypsinization, the epidermis was mechanically torn apart and vigorously washed to release epidermal cells. The epidermal cell suspension was filtered through a $100 \mu \mathrm{m}$ nylon mesh (BioDesign, Saco, Maine, USA) and centrifuged at $200 \mathrm{~g}$ for 10 minutes at $4^{\circ} \mathrm{C}$. Epidermal cells were then placed into $75 \mathrm{~cm}^{2}$ tissue culture dishes (Corning Incorporated, Corning, NY, USA) at a cell density of $4 \times 10^{5}$ cells $/ \mathrm{cm}^{2}$. Cells were washed with fresh culture media 12-18 hours after seeding to remove floating cells from the culture. Fresh culture media was put on cells three times weekly. Primary cultures reached $\sim 90 \%$ confluence in 7-9 days. Confluent primary cultures were treated with $0.05 \%$ EDTA in PBS and cells were harvested by a short, 1-2 minute 
trypsinization with $0.01 \%$ trypsin (Gibco). Trypsinization of cultured epidermal cells provides an almost $100 \%$ pure melanocyte culture sometimes even after the first passage, but always after the second, because melanocytes release from the culture dish much faster than keratinocytes (Figure 3). Harvested cells were divided into two equal parts at passages. Cultures were grown at $37^{\circ} \mathrm{C}$ in humidified atmosphere containing $5 \% \mathrm{CO}_{2}$.
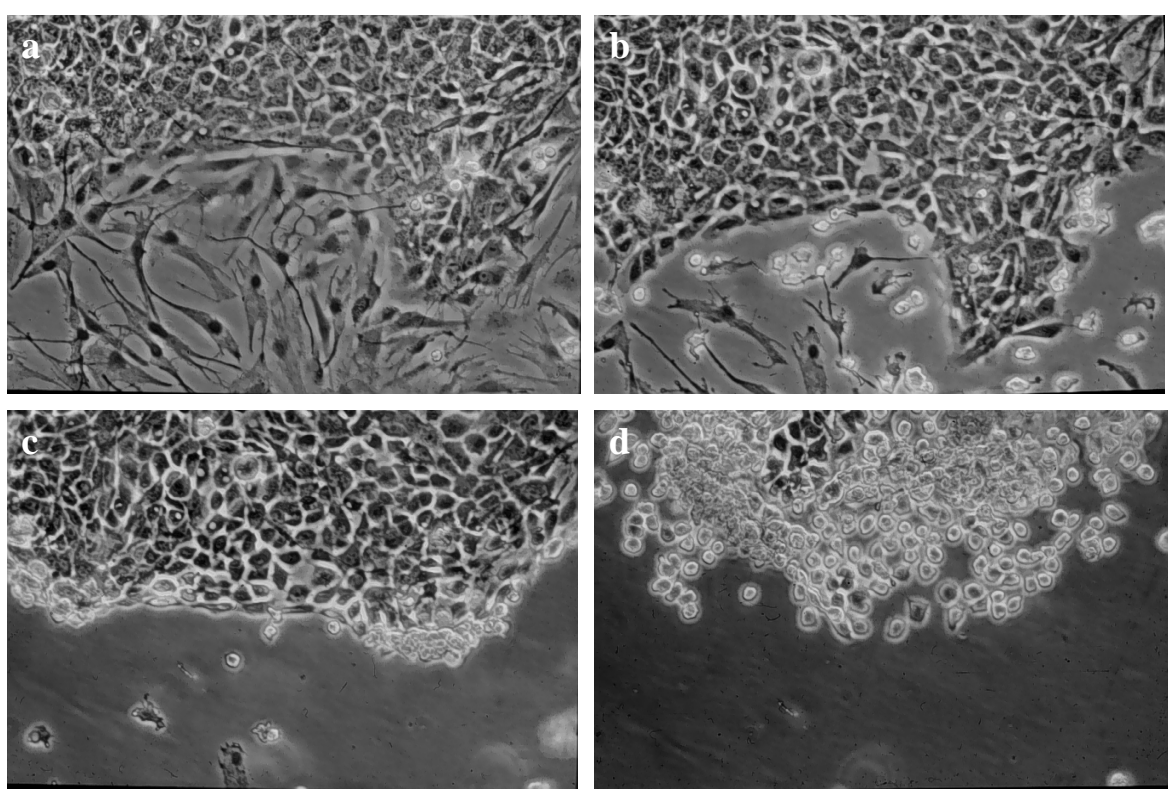

Figure 3. - With trypsinization melanocytes and keratinocytes can be separated during the first passage. $\mathrm{a}-$ start; $\mathrm{b}-1$ minute after trypsinization; $\mathrm{c}$ -2 minutes after trypsinization; $\mathrm{d}-3$ minutes after trypsinization.

\subsubsection{Measurement of cell growth}

The growth of cultured melanocytes was measured using a rapid colorimetric assay, which determines cell numbers (Mosmann et al., 1983) by the reduction of MTT (3-(4,5dimethylthiazol-2-yl)-2,5-diphenyltetrazolium bromide) in living cells. Cells were seeded into 96-well culture plates at a density of $2-5 \times 10^{3}$ cells/well and grown in different culture media for 48, 72, 144 and 192 hours. The supernatant was then replaced with $0.5 \mathrm{mg} / \mathrm{ml}$ MTT solution (Sigma) in RPMI without phenol-red. After incubation for 3 hours at $37^{\circ} \mathrm{C}$, the medium was gently removed from each well and the crystallized dye was solubilized with $2 \% \mathrm{SDS}$ and $0.04 \mathrm{mM} \mathrm{HCl}$ in absolute isopropanol. The optical density of the color reaction was determined by a Multiscan Ex spectrophotometer (Thermo Labsystems, Vantaa, Finland) and Ascent Software (Thermo) at $540 \mathrm{~nm}$. 


\subsubsection{Transplantation}

Keratinocyte cultures have been established and expanded from the different donor sites selectively in vitro. Patients were transplanted with autologous keratinocytes using the Tissucol system from Baxter (Figure 4, 5).
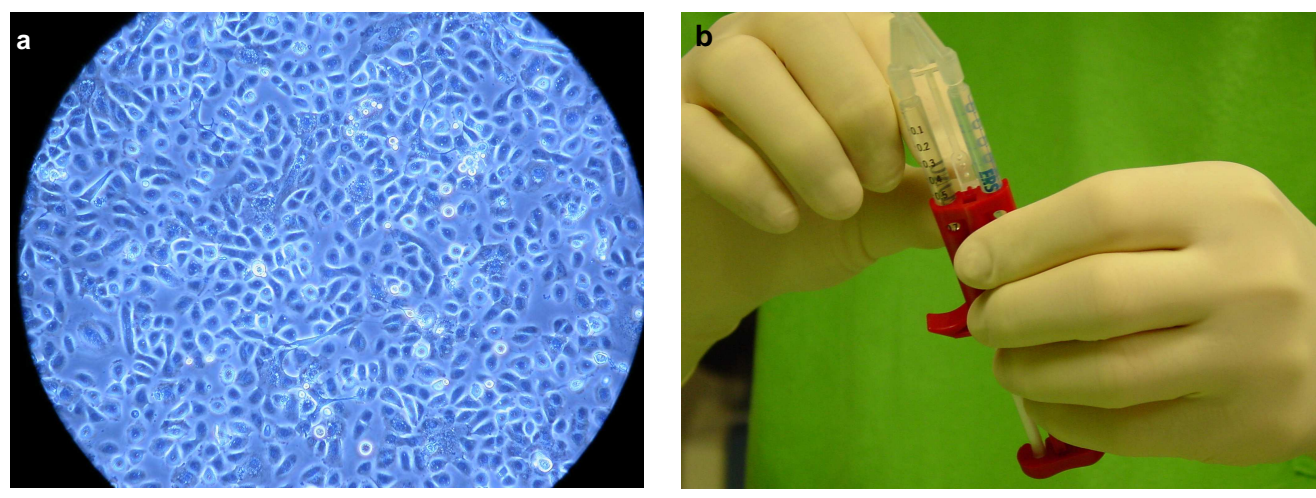

Figure 4. - From cell culture to transplantation

a - keratinocyte/melanocyte culture; b - Tissucol $^{\circledR}$ system used for transplantation.
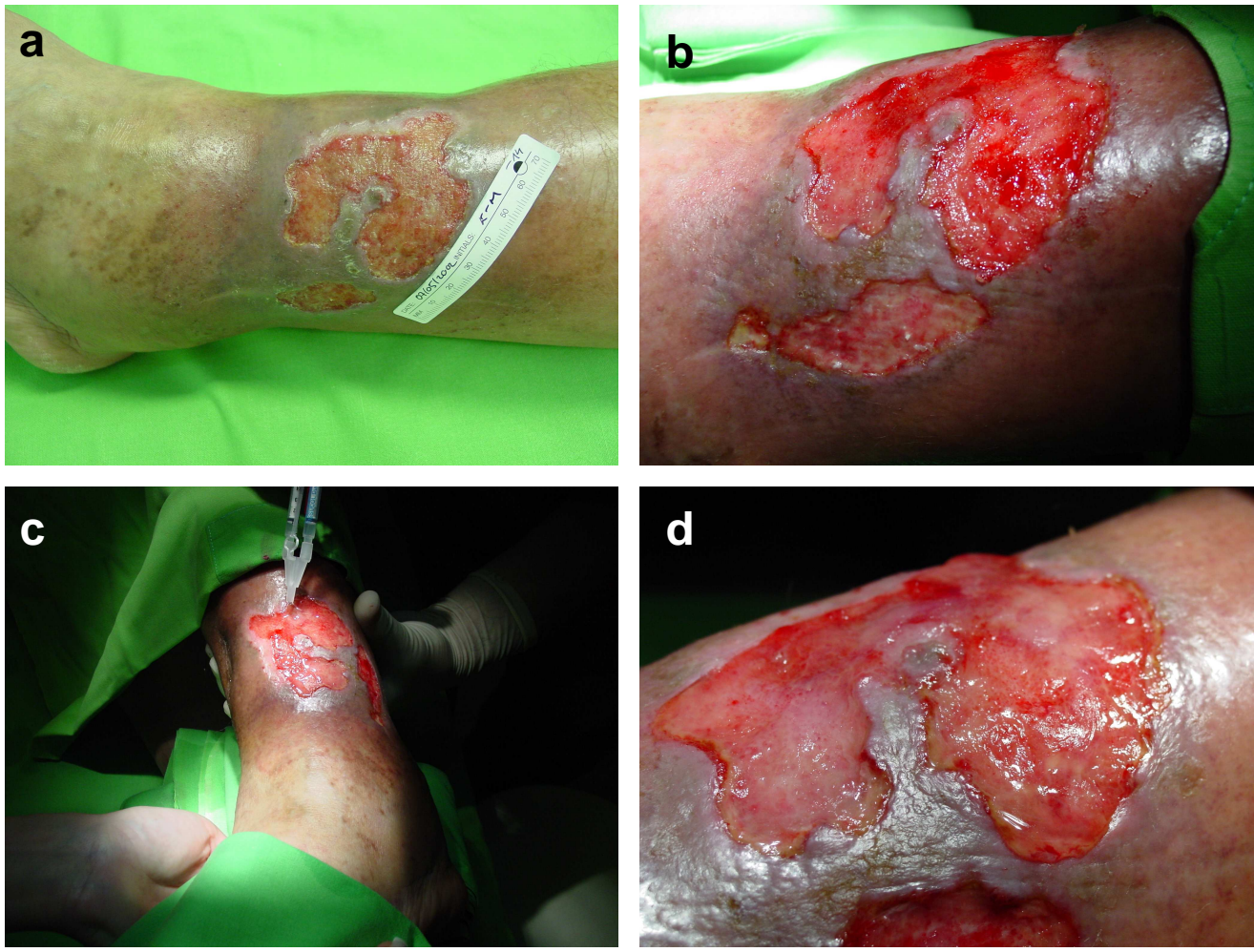

Figure 5. - Autologous keratinocyte transplantation

$\mathrm{a}$ - initial state of the ulcer; $\mathrm{b}$ - ulcer after debridement

$c-$ transplantation with the Tissucol ${ }^{\circledR}$ system; $d-$ ulcer after transplantation 


\section{RESULTS}

\subsection{Genetic studies}

\subsubsection{Predisposing polymorphisms}

\subsubsection{SNP in the 3' untranslated region of the FGFR2 gene (2451A/G)}

Comparison of the SNP data on venous leg ulcer patients $(n=82)$ with those on healthy individuals $(\mathrm{n}=82)$ we identified an SNP located in the 3' untranslated region (UTR) of FGFR2 $(2451 \mathrm{~A} \rightarrow \mathrm{G} ; 900 \mathrm{bp}$ downstream from the open reading frame), which displayed a significant difference in the allelic distribution between the leg ulcer patients and the healthy individuals $(\mathrm{P}=0.0103)$. Our results permitted the conclusion that the expression of the FGFR2-IIIb isoform is related to the proliferation states of the keratinocytes. The fact that FGFR2-IIIb exhibits a lower expression level in venous leg ulcer patients suggests a receptor dysfunction which, through impairment of the proliferation phase of re-epithelization, leads to pathologic wound healing in these patients. A possible underlying mechanism for the abnormal expression of FGFR2-IIIb seen in venous leg ulcer patients may be the presence of the 2451 A/G 3'UTR SNP, which could alter the stability of the mRNA and thus results in decreased amounts of FGFR2 protein and receptor dysfunction. In this case, both the reepithelization through FGFR2-IIIb and the angiogenesis through FGFR2-IIIc may be impaired (Figure 6).

\subsubsection{SNP in the promoter region of the $T N F \alpha$ gene $(-308 \mathrm{G} / \mathrm{A})$}

Our results revealed that the association between the -308 G/A TNF $\alpha$ SNP and venous leg ulceration depends strongly on the number of obese individuals enrolled in the study. Another potential factor involved in venous leg ulcer development could be the presence of the A nucleotide in the $-308 \mathrm{TNF} \alpha \mathrm{SNP}$, though our data suggest that this association with leg ulceration is secondary and the primary association is probably with obesity (Figure 6). 


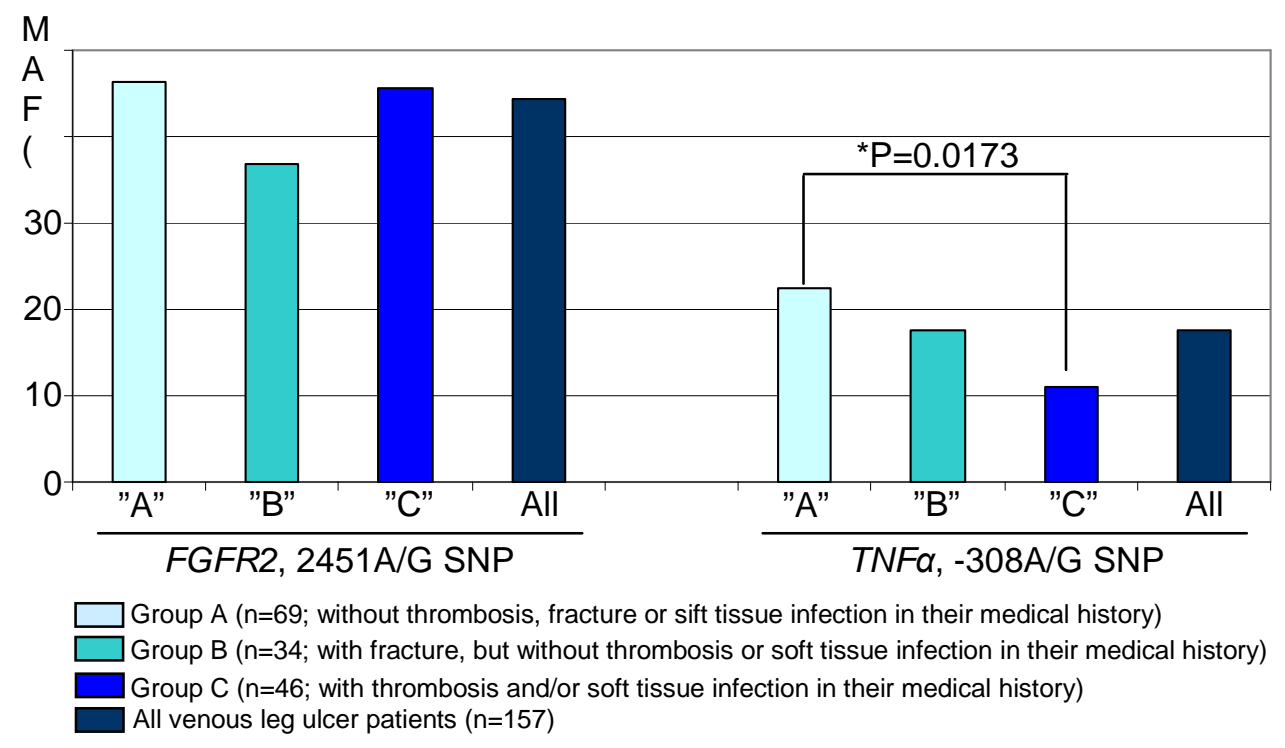

Figure 6. - Mutant allele frequencies (MAF) of the FGFR2, $2451 \mathrm{~A} / \mathrm{G}$ and $T N F \alpha,-308$ A/G SNPs in the subgroups of venous leg ulcer patients.

\subsubsection{Gene expression abnormalities}

Syndecan 4 (SDC4), a heparan sulfate proteoglycan, and neuropilin 1 (NRP1), a transmembrane receptor, are both involved in normal wound healing, but little is known about their possible role in venous leg ulcer pathogenesis. We aimed to investigate whether there are any expression abnormalities and/or gene polymorphisms of SDC4 and NRP1 associated with venous leg ulcer. SDC4 showed significantly lower mRNA and protein expression levels in the uninvolved dermis of venous leg ulcer patients $(n=15)$ as compared with controls $(n=15$; $\mathrm{P}=0.0136$ ), while NRP1 showed no expression abnormalities. We hypothesize that SDC4 may play an essential role not only in the inflammation and tissue formation phases of normal wound healing but its expression abnormalities observed in the uninvolved dermis of venous leg ulcer patients may contribute to venous leg ulcer development. 


\subsection{Local wound care studies}

\subsubsection{Artificial chemical mitogen free method to culture human adult melanocytes and}

\section{keratinocytes}

In the Mel-mix medium (AIM-V and Keratinocyte Basal Medium (KBM) (v:v) supplemented with $2.5 \%$ fetal bovine serum, $2.5 \mathrm{ng} / \mathrm{ml}$ epidermal growth factor, $25 \mu \mathrm{g} / \mathrm{ml}$ bovine pituitary extract) normal human adult melanocytes grew in vitro without chemical mitogens. To compare our cultured cells to cells grown in conventional TPA containing medium, melanocytes from the same skin specimen were cultured simultaneously with $10 \mathrm{ng} / \mathrm{ml}$ TPA in the complete Mel-mix medium. Melanocytes cultured in the presence of TPA had a highly dendritic appearance showing multiple dendritic processes, well developed ramifications and an overall delicate architecture when compared to their TPA-free counterparts. Multiple contacts developed among the cells grown with TPA. Melanocytes cultured in the TPA-free medium also showed the typical dendritic appearance, but dendritic projections were notably more voluminous and cell contacts were notably less. As both culture types matured and grew toward confluency, cells started to show a tripolar or bipolar spindle-shaped morphology. Cells typically became polygonal and flat in senescence in both cultures (Figure 7). 


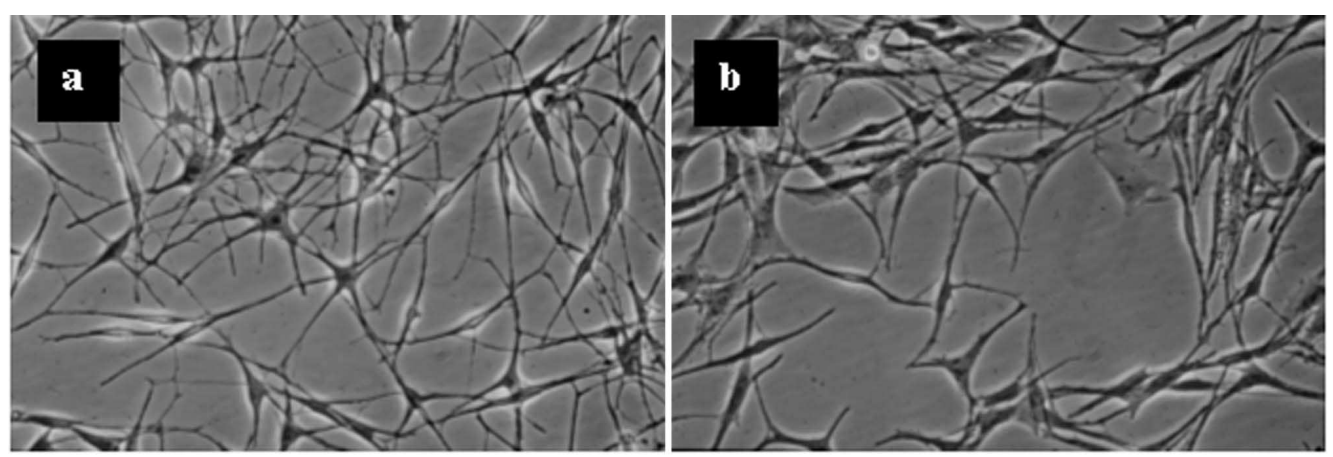

C

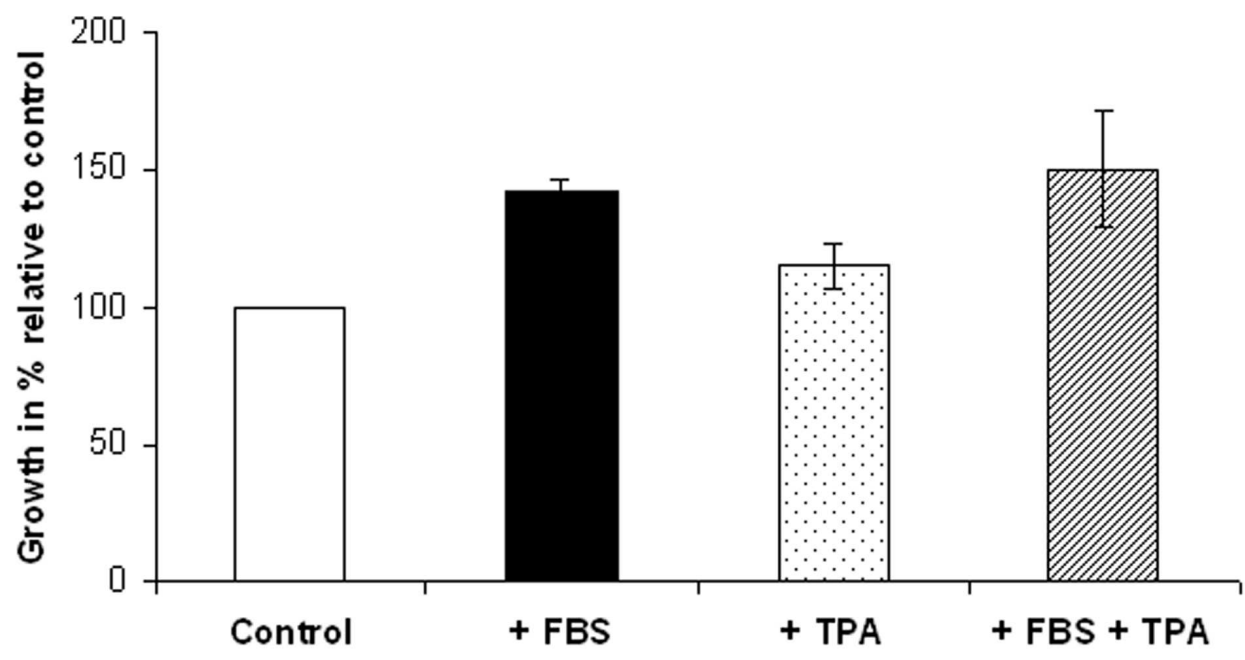

Figure 7. - Human epidermal melanocytes cultured in complete Mel-mix medium. with (a) and without TPA (b) exhibit typical melanocyte morphology. Magnification: 200x. Cells in $5^{\text {th }}$ passage were cultured for 3 days in serum free Mel-mix medium (control, open bar) and in the presence of $2.5 \%$ FBS (solid bar), $10 \mathrm{ng} / \mathrm{ml} \mathrm{TPA} \mathrm{(dotted} \mathrm{bar)} \mathrm{or} \mathrm{both} \mathrm{(striped} \mathrm{bar)} \mathrm{and} \mathrm{cell}$ numbers were determined by MTT assay (c). Bars show means \pm SEM of three independent experiments, each from 8 samples.

To study the effect of TPA on the in vitro cell growth of normal human epidermal melanocytes, melanocytes cultured in complete Mel-mix medium until the $4^{\text {th }}$ passage were harvested, then plated into 96 -well plates at a density of $5 \times 10^{3}$ cells/well. Cells were then grown for 72 hours either in serum- and supplement-free Mel-mix or in serum supplemented Mel-mix medium with and without $10 \mathrm{ng} / \mathrm{ml}$ TPA. TPA alone increased the number of viable cells, in the cultures by $15.2 \pm 8.5 \%$, while the addition of $2.5 \%$ FBS alone caused a 
$42.3 \pm 4.1 \%$ increase in cell number compared to the supplement- and serum-free control medium. TPA and $2.5 \%$ FBS together showed a $50.4 \pm 20.6 \%$ increase in cell number. When compared to the supplement-free Mel-mix medium neither FBS, nor TPA or the two together had a significant growth stimulatory effect on the cells (ANOVA, $\mathrm{P}<0.05$ ).

To determine cell growth and the effect of different growth factors in our chemical mitogen-free Mel-mix medium, a series of MTT assays were carried out using different culture conditions (Figure 8 ). Melanocyte growth in the $4^{\text {th }}$ passage was measured at three time points during an 8-day long culture period. The following culture conditions were tested: supplement-free AIM-V + KBM; 2.5\% FBS supplemented AIM-V + KBM; 2.5\% autologous human serum (AHS) supplemented AIM-V + KBM; complete Mel-mix medium (AIM-V + $\mathrm{KBM}+2.5 \% \mathrm{FBS}+2.5 \mathrm{ng} / \mathrm{ml} \mathrm{EGF}+25 \mu \mathrm{g} / \mathrm{ml} \mathrm{BPE}) ; 2.5 \%$ AHS $+2.5 \mathrm{ng} / \mathrm{ml} \mathrm{EGF}+$ $25 \mu \mathrm{g} / \mathrm{ml}$ BPE supplemented AIM-V + KBM; 2.5\% AHS + $2.5 \mathrm{ng} / \mathrm{ml}$ EGF supplemented AIM-V + KBM, and 2.5\% AHS + $25 \mu \mathrm{g} / \mathrm{ml}$ BPE supplemented AIM-V + KBM. Two days after plating, the numbers of viable cells were the same in all cultures. By day 6 , the numbers of viable cells were higher in all supplemented cultures compared to the supplement-free control medium. With the exception of the $2.5 \%$ FBS supplemented medium cell numbers tripled in all other cultures. During the 8-day culture period, cells only survived, but not proliferated in the AIM-V + KBM basal control medium (Mel-mix). At the end of the 8-day culture period cell numbers were 4-5 times higher in all cultures that contained serum and either one or both additional growth factors (EGF and BPE). Although enhanced cell growth occurred in both serum (FBS and AHS) supplemented cultures, these cell number increases were not significantly different from control (AIM-V $+\mathrm{KBM}$ ) cultures. Compared to the supplement free control basal medium cell numbers increased by $105.0 \pm 48.9 \%$ in the FBS supplemented and $260.0 \pm 97.3 \%$ in the AHS supplemented cultures. Cell growth was significantly enhanced in all other cultures, where in addition to serum either EGF or BPE or both were present in the medium (ANOVA, $\mathrm{P}<0.05$ ). Our data indicate that when compared to FBS, AHS is at least as good, even somewhat better growth supplement for melanocytes. Although the highest increase in cell numbers occurred in the medium that contained AHS and both EGF and BPE, AHS together with only the recombinant EGF resulted in a slightly lower increase in cell numbers. 


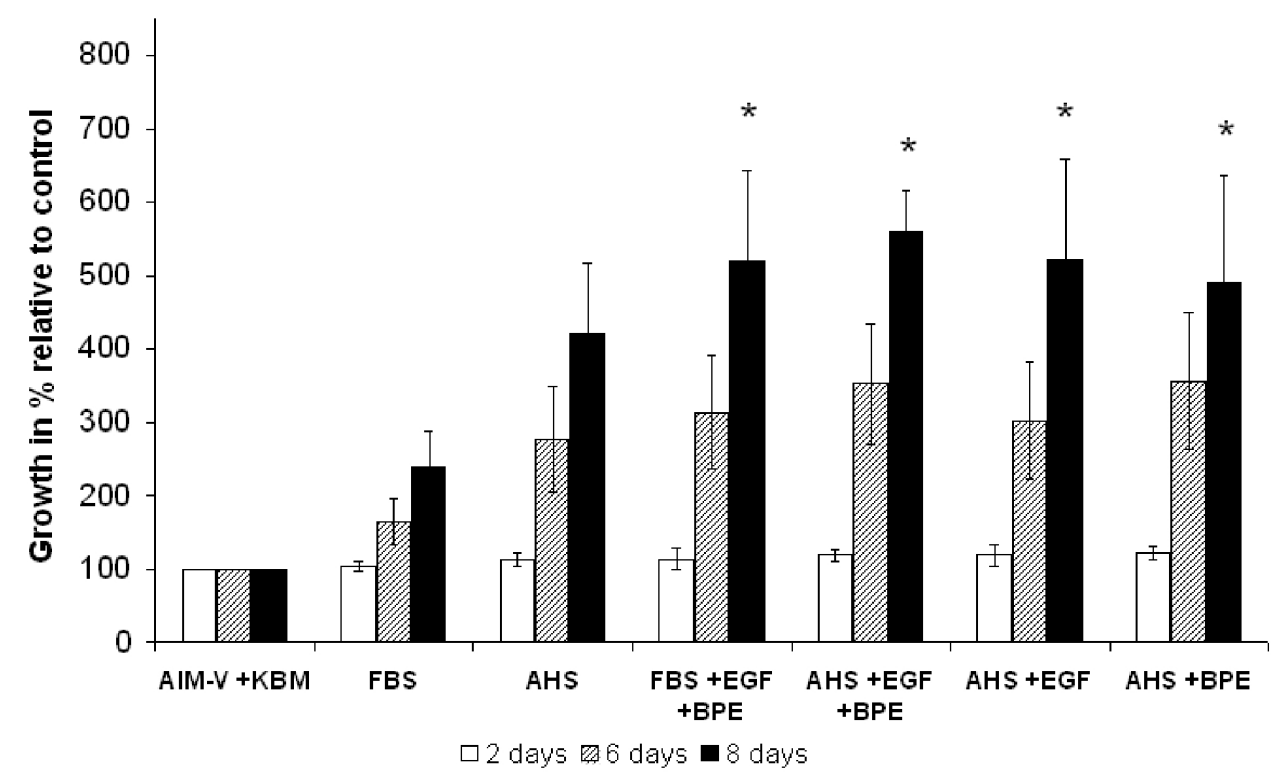

Figure 8. - Comparison of in vitro melanocyte growth in different culture conditions. Melanocytes in $4^{\text {th }}$ passage were cultured in AIM-V $+\mathrm{KBM}$ with different supplements to compare their effect on cell growth. Cell numbers were determined by MTT assay two, six and eight days after plating. Bars show means \pm SEM from three independent experiments, each from 8 samples. *significantly different from the control (ANOVA, $\mathrm{P}<0.05$ ) 


\subsubsection{Hairy scalp the ideal donor site for split thickness and autologous keratinocyte- melanocyte transplantation}

Analyses of freshly isolated keratinocytes from hairy scalp skin showed that the percentage of the p63 positive cells was significantly higher $(39.8 \pm 12.0 \%)$ as compared to upper leg $(31.7 \pm 8.3 \%, \mathrm{P}=0.007)$ or groin $(27.8 \pm 16.0, \mathrm{P}=0.03)$. The percentage of $\mathrm{K} 1 / \mathrm{K} 10$ negative cells was also significantly higher $(52.6 \pm 10.2 \%)$ than in the case of keratinocytes separated from groin $(35.4 \pm 4.5 \%, \mathrm{P}=0.018)$ or from the upper leg $(36.1 \pm 3.2 \%, \mathrm{P}=0.028)$. Moreover hairy scalp yielded a higher number of epidermal cells from the same size of skin specimen (Figure 9).
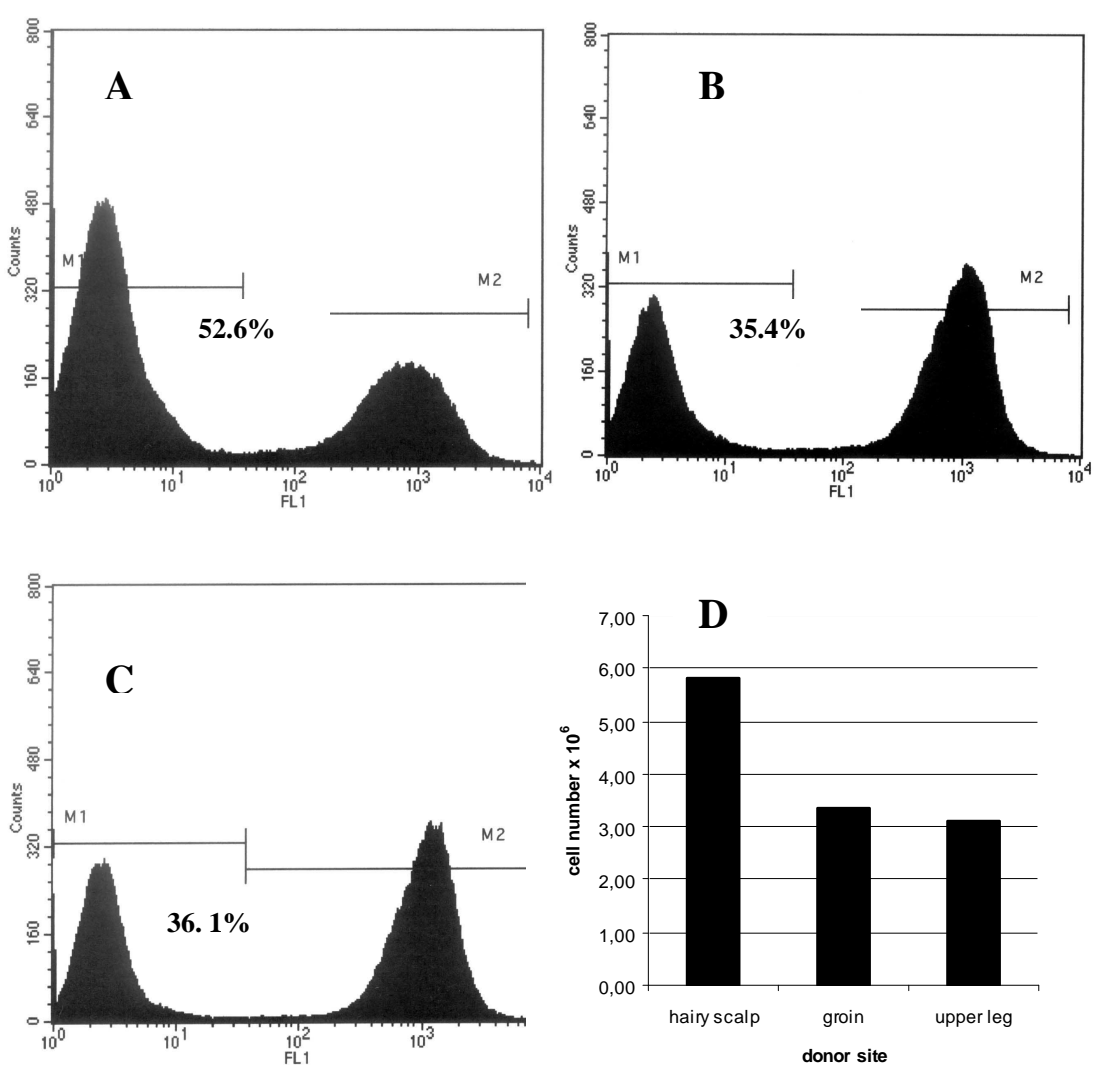

Figure 9. - Representative histograms of freshly isolated keratinocytes stained for K1/K10 keratins. Higher percentage of K1/K10 negative cells are present in samples derived from hairy scalp (A), compared to that separated from the groin (B) and the upper leg (C) after isolation. Cell numbers in epidermal cell suspension prior to plating (D). Significantly higher number of epidermal cells was separated from the hairy scalp. 


\subsubsection{Autologous keratinocyte transplantation in wound healing}

A time as short as two weeks of culturing was sufficient to achieve the suitable cell number for transplantation $\left(3 \times 10^{6} / 100 \mathrm{~cm}^{2}\right)$ in the case of cells derived from hairy scalp biopsies, compared to 3 to 4 weeks in case of the groin and the upper leg biopsies.

We used autologous keratinocyte transplantation in 18 patients. The gender ratio was 12 female/6 male. The mean age was 65 years. All transplanted ulcers were of venous origin. Transplantation was only performed once using the Baxter Tissucol ${ }^{\circledR}$ system (Figure 10).
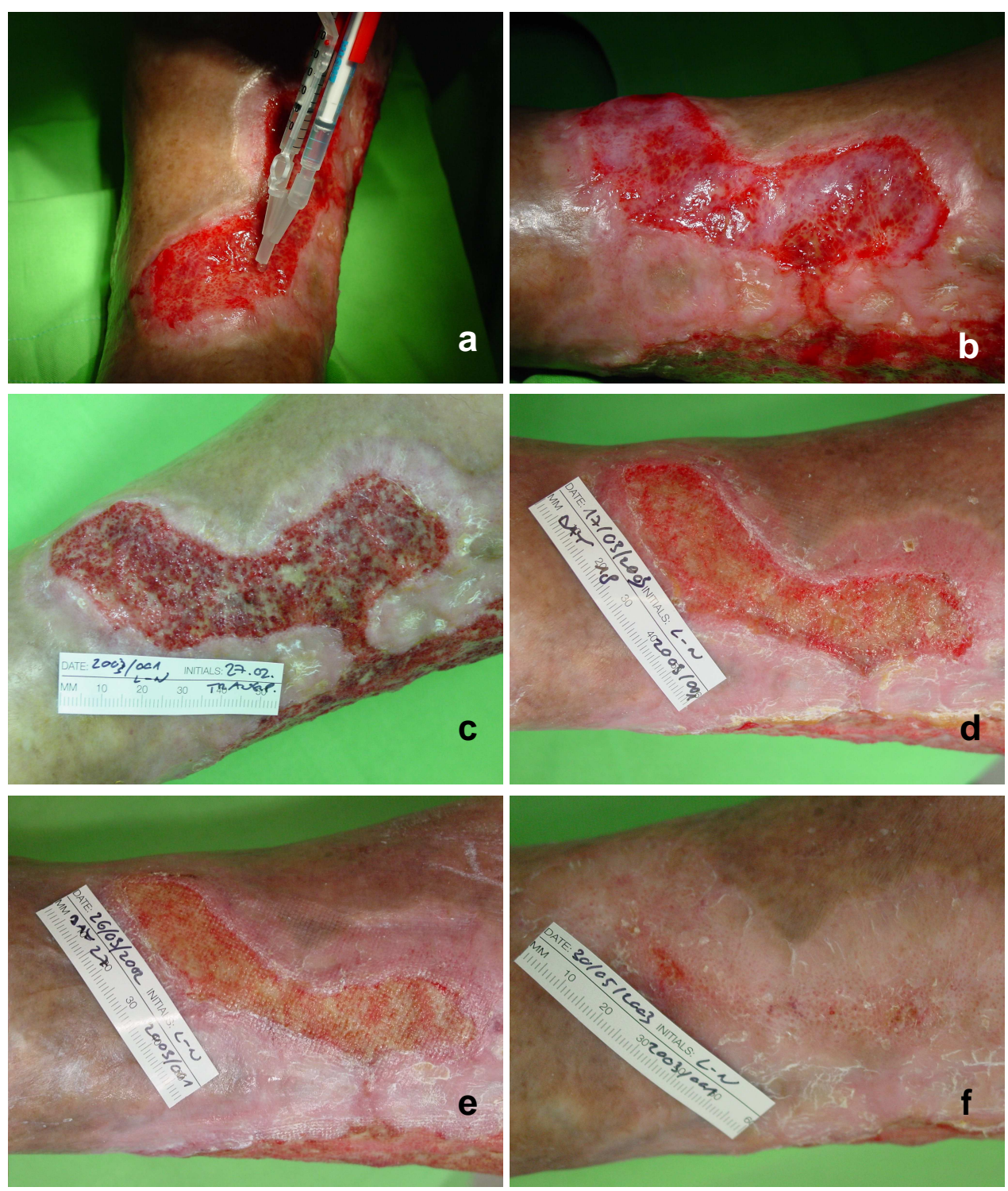

Figure 10. Autologous keratinocyte transplantation of a chronic venous ulcer. a - transplantation with the Baxter Tissucol ${ }^{\circledR}$ system; b - the freshly transplanted wound surface; $\mathrm{c}$ - day $0,25 \mathrm{~cm}^{2} ; \mathrm{d}$ - day $18,15 \mathrm{~cm}^{2}$ e - dav $27,9 \mathrm{~cm}^{2}$; f - 9 weeks, healed. 


\subsubsection{Split-skin grafting from the hairy scalp in wound healing}

Due to the results of autologous keratinocyte transplantation from the hairy scalp, we decided to use the hairy scalp as a donor site for split skin grafting of chronic wounds. Hairy scalp is ideal because of the abundant number of keratinocyte stem cells in the bulge area and because of innumerous capillaries in this region. So far we have accomplished 45 transplantations from the hairy scalp, with a gender ratio of 27 female/18 male. The mean age was 63 years. In 15 cases we used V.A.C. fixation, in 30 cases Inadine as a primary wound dressing. V.A.C. was removed after 5 days, while primary dressing was changed after 2 days (Figure 11, 12, 13).
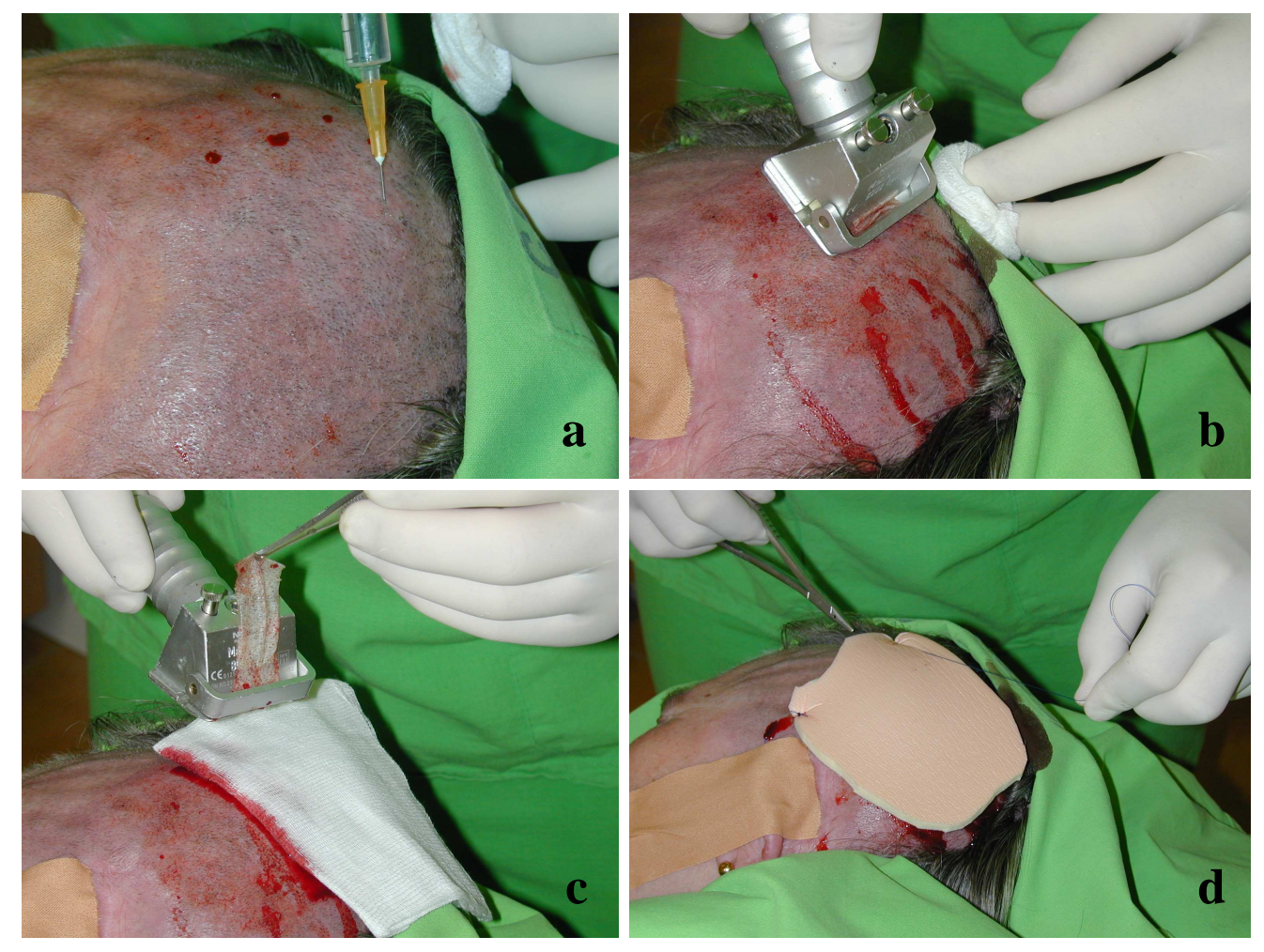

Figure 11. Hairy scalp as donor site for split-skin grafting. a - local anesthesia of the hairy scalp; $\mathrm{b}$ - taking the spit-skin graft with a dermatome; $\mathrm{c}$ - the split-skin-graft; $\mathrm{d}$ - the primary foam dressing is sutured to the scalp 

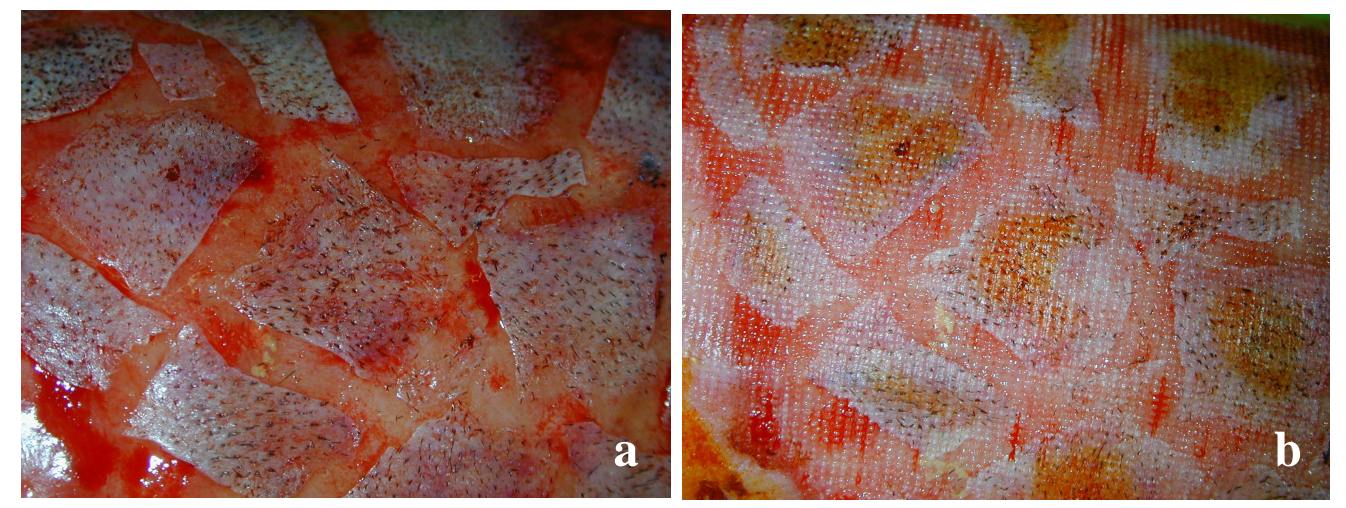

Figure 12. Split-skin grafts from the hairy scalp. a - transplantation day ; b - 72 hours after transplantation, all grafts are vital
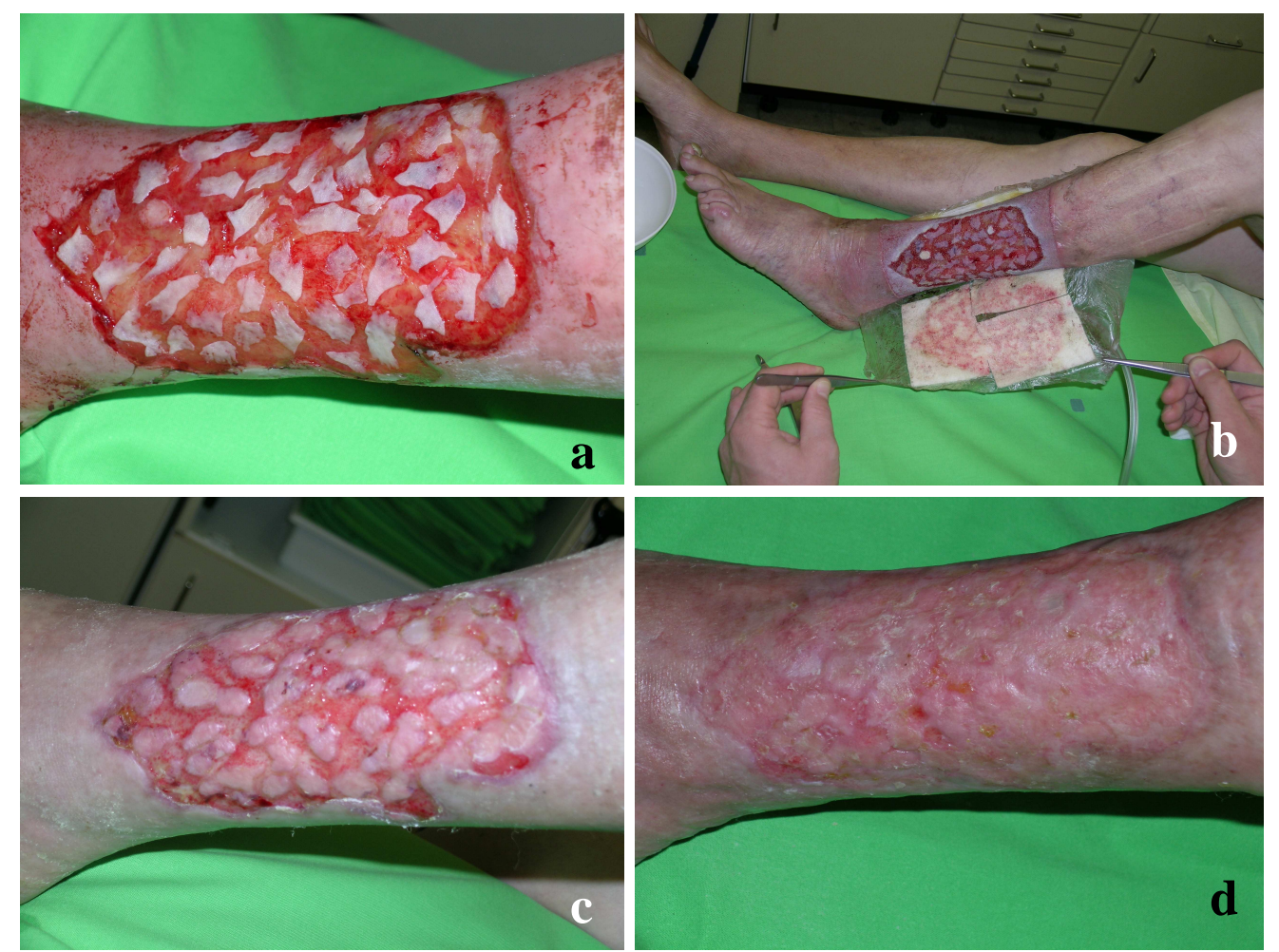

Figure 13. Split-skin transplantation from the hairy scalp with V.A.C. fixation a - day of transplantation; b - V.A:C. removal on day 5, all grafts are vital; c - day 7, spontaneous epithelisation can be seen between the grafts; $\mathrm{d}$ - day 14 , ulcer is healed 


\section{SUMMARY}

In the genetic studies we compared the SNP data of leg ulcer patients with healthy individuals for FGFR2-IIIb isoforms. The results showed that FGFR2-IIIb exhibits a lower expression level in venous leg ulcer patients, which will result in the impairment of reepithelisation, thus pathologic wound healing. The SNP data for the promoter region of the $T N F \alpha$ gene suggested a primary association with obesity and only a secondary association with leg ulceration.

We also set out to determine the expression abnormalities and/or gene polymorphisms of SDC4 and NRP1. We found out that SDC4 showed a significantly lower mRNA and protein expression levels in the uninvolved dermis of venous leg ulcer patients as compared to normal controls. In the case of NRP1 no expression abnormalities were detected.

In the cell culturing experiments, we established a chemical and artificial mitogen free autologous keratinocyte/melanocyte culturing technique. We developed a special culture media to suit the needs of melanocytes as well as keratinocytes. This method enables the preparation of autologous skin cell cultures suitable for the grafting of chronic wounds. Furthermore and with the use of the hairy scalp as a donor site we established cultures that consisted primarily of keratinocytes stem cells. This autologous skin cell culture was successfully applied for the grafting of chronic leg ulcers with the Tissucol ${ }^{\circledR}$ system.

With the knowledge of the culturing results, we developed a split skin grafting technique for the transplantation of chronic leg ulcers. The split skin grafts taken from the hairy scalp were used for grafting with V.A.C. fixation of the grafts on the wound bed. With the combination of the hairy scalp and the V.A.C. technique all the grafts attached and vitalized on the wound bed. 


\section{DISCUSSION}

\section{Genetic studies}

Leg ulceration is a multifactorial disorder with several known and yet unknown environmental and genetic factors contributing to its etiology. Our genetic studies are restricted to a homogenic subgroup of venous leg ulcers. However the complexity of venous leg ulcer pathogenesis is increased by the fact that in the majority of the cases its development is of polyetiological origin. Besides environmental factors, several predisposing genetic factors have already been shown to be associated with venous leg ulcer susceptibility such as the presence of certain gene polymorphisms and gene expression abnormalities. These genetic factors impair different processes and phases of wound healing that might suggest that complex molecular mechanisms of venous leg ulcer development exist, similarly to carcinogenesis were the co-existence of different predisposing factors leads to the development of the disease. To develop causative treatment opportunities for those who have genetic deficiencies in the pathogenesis, there is an emerging importance to characterize the genetic abnormalities of leg ulcer development.

The difficulties of the studies - with respect to the molecular mechanisms of pathologic wound healing - stem from the fact that these inherited factors form a complex multifactorial genetic background which does not follow the Mendelian rules. Moreover each genetic component contributes differently to the pathogenesis of leg ulcers and the assessment of its importance in the development of leg ulcers is difficult at present. To analyze the putative genetic factors and to minimize statistical bias the currently most widely accepted approach is the formation of highly homogenous subgroups of leg ulcer patients and an assessment of the genetic factors within the subgroups.

Therefore, a homogenous venous leg ulcer patient group has been created with 157 individuals with non-healing ulcers despite of proper-loking therapy. The duration of the presence of the leg ulcer exceeded 6 weeks. The female $(48.4 \%)$ male $(51.6 \%)$ ratio was nearly $1: 1$. The average duration of the ulcers was $5.8 \pm 5.1$ years. The three most frequent and clinically relevant parameters in the history of the patients were: (1) deep vein thrombosis $29.9 \%$, (2) leg fracture $22.9 \%$ and (3) some type of soft tissue infection of the affected lower leg $47.1 \%$ of the patients had erysipelas or cellulites during their former history. These clinical parameters strongly affect the circulation of the leg and contribute to the pathogenesis of venous leg ulcer development. The three subgroups of the patients were further classified 
to reduce statistical fluctuations. Group A contained patients without thrombosis, fracture or soft tissue infection in the history. Patients with fracture, but without thrombosis and soft tissue infection has formed group B. While patients with thrombosis or erysipelas, but without fractures has been placed to group C. Other combinations of fracture, thrombosis and soft tissue infection were represented in such a small number that those patients as all put together in group D. Leg ulcer patients with diabetes of either type 1 or type 2 or with arterial disease were excluded from the study. Venous leg ulcer patients were also screened for cardiac diseases (incidence was 49.1\%), atherosclerosis (incidence was 20.4\%) and autoimmune disorders (incidence was 5.1\%). The study was approved by the Internal Review Board. Written informed consent was obtained from all donors, and the study was conducted according to the Principles of the Declaration of Helsinki.

The importance of several putative genetic factors has been assessed in the homogenous group of venous leg ulcer patients such as the G1691A factor V Leiden mutation, G20210A prothrombin gene mutation, 2451 A/G polymorphism (SNP) of the FGFR2 gene and the $-308 \mathrm{G} / \mathrm{A}$ SNP of the promoter region of the $T N F \alpha$ gene (Jebeleanu et al., 2001, Hafner et al., 2001; Nagy et al., 2005 and 2007). The studies were carried out using RT-PCR with TaqMan probes and RFLP techniques described in previous studies (Jebeleanu et al., 2001, Hafner et al., 2001; Nagy et al., 2005 and 2007). The Leiden mutation was present in heterozygous condition in 11 patients with the overall frequency of $7.9 \%$, showing higher presentation in the group $\mathrm{A}$ and group $\mathrm{C}$ than in group $\mathrm{B}$ (data not shown). The prothrombin mutation occurred also only in 3 patients with heterozygous form, every other patients carried only the wild type allele (data not shown).

The distribution of the mutant genotypes of the studied FGFR2 gene polymorphism (2451A/G SNP at the 3'UTR) was the highest in group A (ratio of homozygous mutants $18.8 \%$, mutant allele frequency $\mathrm{MAF}=0.46$ ), while the lowest in group $\mathrm{B}$ (ratio of homozygous mutants $8.8 \%, \mathrm{MAF}=0.37$, Fisher Exact Probability Test $\mathrm{P}=0.1227$, odds ratio 1.49, CI 0.88 - 1.81;. However it has been proven previously, that the $2451 \mathrm{~A} / \mathrm{G}$ polymorphism in the 3'UTR of the FGFR2 gene is associated with venous leg ulcer development, its distribution did not show significant difference between the subgroups of venous leg ulcer patients defined on the basis of their medical history.

The single nucleotide change of the TNFa promoter also showed the highest frequency in group A (ratio of homozygous mutants 5.8\%, MAF=0.22), while in group B and $\mathrm{C}$ homozygous mutant form was not detected and only the heterozygous form was present (group $\mathrm{B} \mathrm{MAF}=0.18$, group $\mathrm{C} \mathrm{MAF}=0.11$; group $\mathrm{A}$ vs. group $\mathrm{B} \mathrm{P}=0.27$, dds ratio 1.35 , $\mathrm{CI}$ 
0.70 - 2.32; group A vs. group C P=0.02, Odds ratio 2.38, CI 1.07 - 4.01). It has been demonstrated previously that the $-308 \mathrm{~A} / \mathrm{G} \mathrm{SNP}$ of the promoter region of the $T N F \alpha$ gene is a predisposing factor to venous leg ulcer development (Wallace et al., 2006; Nagy et al., 2007). Our data demonstrate that the homozygous mutant form of the -308 TNFa SNP was represented in a significantly higher ratio among venous leg ulcer patients without other predisposing factor in their history (group A: no thrombosis, fracture or soft tissue infection) than among patients with other known etiological event in their history (group C: patients with previous thrombosis or soft tissue infection; group A vs. group C Fisher Exact Probability Test $\mathrm{P}=0.0173$ ). The data further emphasize that the putative etiologic factors analyzed in our study has key importance in the development of therapy-resistant leg ulcer cases and they might have a tremendous significance in the development of future causative treatment strategies.

Several recent studies characterized in details the putative genetic factors that contribute to the development of leg ulcer. However these discoveries have no impact yet on the current guidelines of leg ulcer management and thus they have no clinical relevance yet. Further larger studies in different populations are needed to characterize the underlying genetic abnormalities in the mechanism of leg ulcer development and to work out costeffective techniques for the routine diagnostic assessments of the putative genetic factors and causative treatment options for these patients.

\section{Local wound care studies}

Several methods and several media formulations have been published over the years for the separation and subsequent culturing of human epidermal melanocytes and keratinocytes (Eisinger et al., 1982; Gilchrest et al., 1984; Hu et al., 1957). With few exceptions, all methods used chemical mitogens to enhance cell growth. Co-cultures of melanocytes with keratinocytes in a melanocyte growth medium (MGM) supplemented with EGF, BPE, and FBS resulted in sufficient in vitro melanocyte growth without the need for chemical mitogens (Donatien et al., 1993). The use of basic fibroblast growth factor (bFGF), endothelin-1 (ET-1) and $\alpha$-melanocyte stimulating hormone ( $\alpha$-MSH) have also been reported to be able to replace the need for TPA and BPE in already established in vitro cultures of human neonatal melanocytes (Swope et al., 1995). The culture system that we describe here is unique, in that relatively long term, pure melanocyte cultures, with cells derived from adult epidermis, that are never exposed to chemical mitogens, can be established easily. Although additional growth factor supplementation (e.g. EGF, BPE) increases cell proliferation, the use 
of serum is sufficient to establish and maintain the in vitro culture of these cells in our medium. We found autologous human serum (AHS) to be somewhat superior to FBS in supporting the in vitro melanocyte growth. Cells expanded in vitro in Mel-mix supplemented with autologous human serum allow autologous transplantation of cultured skin cells in chronic wounds and in vitiligo (Lontz et al., 1994; Olsson et al., 1993; Olsson et al., 1995). We offer a novel culturing technique to isolate and culture human epidermal melanocytes and keratinocytes in a chemical mitogen-free environment. With this method it is possible to easily establish pure human epidermal skin cell cultures in which melanocytes propagate sufficiently already in the early passages, when their pigmentation is not lost, therefore they can be transplanted to cover vitiligo lesions. Further work will show whether the in vitro dedifferentiation of the cells that occurs in older cultures can be reversed with agents thet al.low autologous transplantations. Cells grown in our cultures regain their in vitro growth after freezing and storage allowing repeated transplantation from the same harvest in chronic wound and vitiligo patients.

The In vitro culturing technique involves subcultivations to expand the number of keratinocytes. Transplantation techniques of cultured keratinocytes are based on the selfrenewing capacity of the epidermis. This characteristic of the epidermis is the result of the presence of multi-potent stem cells which reside in the bulge region of the hair follicle as well as in the interfollicular epidermis. Epidermal stem cells undergo asymmetric cell division and give rise to daughter stem cells and to transit amplifying cells. After a few rounds of cell division the transit amplifying cells exit from the cell cycle and undergo terminal differentiation. Differentiating keratinocytes constitute a significant percentage of the cultured keratinocytes separated from skin biopsies and in consequence have a finite replicative capacity and lifespan. The increased number of cell divisions in vitro leads to telomeric shortening, which in turn reduces lifespan of the autograft, hence it is of outmost importance to use undifferentiated keratinocytes for autologous transplantation purposes (Counter et al., 2003).

Stem cells and transit amplifying cells are characterized by expression of the transcription factor p63, a member of the p53 gene family. Recent data suggest that p63 has a role in initiating epithelial stratification during development and a role in maintaining the proliferative potential of basal keratinocytes in mature epidermis (Koster et al., 2004). As soon as the transit amplifying cells cease proliferation, the expression of p63 is downregulated and the cells start to produce K1 and K10 keratines. Production of K1 and K10 keratines mirrors the commitment to differentiation and is among the earliest events in the 
program of cellular terminal differentiation (Eichner et al., 1990). The proportion of p63 positive and K1/K10 negative cells in transplanted keratinocytes is important for both short and long term clinical outcomes.

We have shown that the epidermal cell suspension prepared from hairy scalp contains an abundance of undifferentiated keratinocytes as compared to conventional donor sites (groin, upper leg). Considering that stem cells are more abundant in hair follicles, the use of hairy scalp as a donor site provides a keratinocyte culture rich in undifferentiated keratinocytes (Taylor et al., 2000). Therefore, cell cultures prepared from hairy scalp skin specimens can proliferate to yield the required cell number for transplantation in a shorter period as compared to conventional donor sites. Furthermore, the hairy-scalp derived cells have longer lifespan and longer regenerative capacities. The results reported here suggest that keratinocytes and melanocytes isolated and cultured from hairy scalp donor sites are more suitable for autologous transplantation of chronic leg ulcers and burnt skin areas than grafts established from conventional donor sites. Like other epidermal keratinocytes, the cultured cells can be successfully frozen and stored for possible future transplantations, an advantage that should prove useful both for patient and clinician.

\section{FUTURE ASPECTS}

Chronic wound care grew up to be a separate discipline in modern medicine. We are presently at the start of turning anecdotal facts to evidence based medicine in wound care. The palette of wound care dressings is growing day by day making daily decisions harder and harder about local treatment. Besides new dressings, new and sophisticated autologous skin cell culturing and transplantation methods can also be used to treat these chronic wounds. Despite the fact of the "best dressing for all wounds" appearing every now and than a true expert in wound care should never forget: without treating the underlying disease long term success is never achieved. In some cases treating the underlying disease is simply not enough: we demonstrated, that in some patients there are well determined genetic abnormalities behind the existence of the chronic wound.

We truly believe that the success of chronic wound care lies in team approach with setting complex care strategies. The team always consists of an interdisciplinary medical team, the patient and patient's family. Communication and partnership is of outmost importance between these groups. The continuous motivation, setting realistic and achievable 
goals for both medical staff and patient is as important as proper local wound care. Establishing all three pillars of chronic wound care paves the path to healed chronic ulcers. 


\section{ACKNOWLEDGEMENTS}

I express my gratitude to Prof. Dr. Lajos Kemény, Prof. Dr. Zsuzsanna Bata-Csörgő and Prof. Dr. Attila Dobozy for the possibility to carry out the clinical and laboratory work needed for this work at the Department of Dermatology and Allergology, University of Szeged. Thanks to all my co-authors for their support and help, especially Nikoletta Nagy, Bernadett Kormos, Anna Kendressy Szabó and Győző Szolnoky. Many-many thanks to my clinical staff and patients who helped in the enormous clinical work behind this study, especially Judit Vasas and Csilla Sánta. I am grateful to my parents and family for their patience and continuing support over the years.

I dedicate this work especially to my children, Emma and Vendel. 


\section{REFERENCES}

Abbade LP, Lastoria S. Venous ulcer: epidemiology, physiopathology, diagnosis and treatment. Int J Dermatol 2005;44: 449-456.

Ashworth JJ, Smyth JV, Pendleton N et al. The dinucleotide (CA) repeat polymorphism of estrogen receptor beta but not the dinucleotide (TA) repeat polymorphism of estrogen receptor alpha is associated with venous ulceration. J Steroid Biochem Mol Biol 2005;97: 266-270.

Baker SR, Stacey MC, Singh G et al. Aetiology of chronic leg ulcers. Eur J Vasc Surg 1992;6: 245-251.

Boulton AJ. The diabetic foot. Med Clin North Am 1988;72: 1513-1530.

Cheng KI, Lin SR, Chang LL et al. Association of the functional A118G polymorphism of OPRM1 in diabetic patients with foot ulcer pain. J Diabetes Complications 2010;24: 102-108.

Clark RA, Ashcroft GS, Spencer MJ et al. Re-epithelialization of normal human excisional wounds is associated with a switch from alpha $\mathrm{v}$ beta 5 to alpha $\mathrm{v}$ beta 6 integrins. $\mathrm{Br} J$ Dermatol 1996;135: 46-51.

Counter CM, Press W, Compton CC. Telomere shortening in cultured autografts of patients with burns. Lancet 2003;361: 1345-1346.

Crist SA, Elzey BD, Ludwig AT et al. Expression of TNF-related apoptosis-inducing ligand (TRAIL) in megakaryocytes and platelets. Exp Hematol 2004;32: 1073-1081.

DiPietro LA, Reintjes MG, Low QE et al. Modulation of macrophage recruitment into wounds by monocyte chemoattractant protein-1. Wound Repair Regen 2001;9: 28-33.

Donatien P, Surleve-Bazeille JE, Thody AJ et al. Growth and differentiation of normal human melanocytes in a TPA-free, cholera toxin-free, low-serum medium and influence of keratinocytes. Arch Dermatol Res 1993;285: 385-392.

Eichner R, Kahn M. Differential extraction of keratin subunits and filaments from normal human epidermis. J Cell Biol 1990;110: 1149-1168.

Eisinger M, Kahn M. Selective proliferation of normal human melanocytes in vitro in the presence of phorbol ester and cholera toxin. Proc Natl Acad Sci USA 1982;79:2018-2022.

Fowkes FG, Evans CJ, Lee AJ. Prevalence and risk factors of chronic venous insufficiency. Angiology 2001;52 Suppl 1: S5-15.

Frykberg RG, Mendeszoon E. Management of the diabetic Charcot foot. Diabetes Metab Res Rev 2000;16 Suppl 1: S59-S65 .

Gemmati D, Federici F, Catozzi L et al. DNA-array of gene variants in venous leg ulcers: detection of prognostic indicators. J Vasc Surg 2009;50: 1444-1451. 
Gemmati D, Tognazzo S, Serino ML et al. Factor XIII V34L polymorphism modulates the risk of chronic venous leg ulcer progression and extension . Wound Repair Regen 2004;12 : 512-517.

Gilchrest BA, Vrabel MA, Flynn E et al. Selective cultivation of human melanocytes from newborn and adult epidermis. J Invest Dermatol 1984;83: 370-376.

Hafner J, Kuhne A, Schar B et al. Factor V Leiden mutation in postthrombotic and nonpostthrombotic venous ulcers. Arch Dermatol 2001;137: 599-603.

Holmbeck K, Szabova L. Aspects of extracellular matrix remodeling in development and disease. Birth Defects Res C Embryo Today 2006;78: 11-23.

Hotamisligil GS, Arner P, Atkinson RL et al. Differential regulation of the p80 tumor necrosis factor receptor in human obesity and insulin resistance. Diabetes 1997;46: 451-455.

Hu F, Staricco RJ, Pinkus H et al. Human melanocytes in tissue culture. J Invest Dermatol 1957;28: 15-32.

Jebeleanu G, Procopciuc L. G20210A prothrombin gene mutation identified in patients with venous leg ulcers. J Cell Mol Med 2001;5: 397-401.

Kitano Y, Okada N. Separation of the epidermal sheet by dispase. Br J Dermatol 1983;108: 555-560.

Koster MI, Roop DR. The role of p63 in development and differentiation of the epidermis. $J$ Dermatol Sci 2004;34: 3-9.

Laurens N, Koolwijk P, de Maat MP. Fibrin structure and wound healing. J Thromb Haemost 2006;4: 932-939.

Lontz W, Olsson MJ, Moellmann G et al. Pigment cell transplantation for treatment of vitiligo: a progress report. J Am Acad Dermatol 1994;30: 591-597.

Maas-Szabowski N, Szabowski A, Stark HJ et al. Organotypic cocultures with genetically modified mouse fibroblasts as a tool to dissect molecular mechanisms regulating keratinocyte growth and differentiation. J Invest Dermatol 2001;116: 816-820.

Mir KA, Pugazhendhi S, Paul MJ et al. Heat-shock protein 70 gene polymorphism is associated with the severity of diabetic foot ulcer and the outcome of surgical treatment. $\mathrm{Br} J$ Surg 2009;96: 1205-1209.

Mosmann T. Rapid colorimetric assay for cellular growth and survival: application to proliferation and cytotoxicity assays. J Immunol Methods 1983;65: 55-63.

Munkvad S, Jorgensen M. Resistance to activated protein C: a common anticoagulant deficiency in patients with venous leg ulceration. Br J Dermatol 1996;134: 296-298.

Nagy N, Szolnoky G, Szabad G et al. Single nucleotide polymorphisms of the fibroblast growth factor receptor 2 gene in patients with chronic venous insufficiency with leg ulcer. $J$ Invest Dermatol 2005;124: 1085-1088. 
Nagy N, Szolnoky G, Szabad G et al. Tumor necrosis factor-alpha -308 polymorphism and leg ulceration--possible association with obesity. J Invest Dermatol 2007;127: 1768-1769.

Nissen NN, Polverini PJ, Koch AE et al. Vascular endothelial growth factor mediates angiogenic activity during the proliferative phase of wound healing. Am J Pathol 1998;152: $1445-1452$.

Olsson MJ, Juhlin L. Repigmentation of vitiligo by transplantation of cultured autologous melanocytes. Acta Derm Venereol 1993;73: 49-51.

Olsson MJ, Juhlin L. Transplantation of melanocytes in vitiligo. Br J Dermatol 1995;132: 587-591.

Paladini RD, Takahashi K, Bravo NS et al. Onset of re-epithelialization after skin injury correlates with a reorganization of keratin filaments in wound edge keratinocytes: defining a potential role for keratin 16. J Cell Biol 1996;132: 381-397.

Peus D, von Schmiedeberg S, Pier A et al. Coagulation factor V gene mutation associated with activated protein $\mathrm{C}$ resistance leading to recurrent thrombosis, leg ulcers, and lymphedema: successful treatment with intermittent compression. J Am Acad Dermatol 1996;35: 306-309.

Phillips TJ, Dover JS. Leg ulcers. J Am Acad Dermatol 1991;25: 965-987.

Singer AJ, Clark RA. Cutaneous wound healing. N Engl J Med 1999;341: 738-746.

Streit M, Beleznay Z, Braathen LR. Topical application of the tumour necrosis factor-alpha antibody infliximab improves healing of chronic wounds. Int Wound J 2006;3: 171-179.

Swope VB, Medrano EE, Smalara D et al. Long-term proliferation of human melanocytes is supported by the physiologic mitogens alpha-melanotropin, endothelin-1, and basic fibroblast growth factor. Exp Cell Res 1995;217: 453-459.

Taylor G, Lehrer MS, Jensen PJ et al. Involvement of follicular stem cells in forming not only the follicle but also the epidermis. Cell 2000;102: 451-461.

Toumi H, F'guyer S, Best TM. The role of neutrophils in injury and repair following muscle stretch. J Anat 2006;208: 459-470.

Wallace HJ, Vandongen YK, Stacey MC. Tumor necrosis factor-alpha gene polymorphism associated with increased susceptibility to venous leg ulceration. J Invest Dermatol 2006;126: 921-925.

Werner S, Smola H, Liao X et al. The function of KGF in morphogenesis of epithelium and reepithelialization of wounds. Science 1994;266: 819-822.

Young MJ, Boulton AJ, MacLeod AF et al. A multicentre study of the prevalence of diabetic peripheral neuropathy in the United Kingdom hospital clinic population. Diabetologia 1993;36: 150-154.

Zamboni P, Tognazzo S, Izzo M et al. Hemochromatosis C282Y gene mutation increases the risk of venous leg ulceration. J Vasc Surg 2005;42: 309-314. 